Cross-Border Lending and the International Transmission of Banking Crises

Daniel Dieckelmann

School of Business \& Economics

Discussion Paper

Economics

2020/13 


\title{
Cross-Border Lending and the International Transmission of Banking Crises
}

\author{
Daniel Dieckelmann* \\ Freie Universität Berlin
}

July 9, 2020

\begin{abstract}
This paper introduces a new transmission channel of banking crises where sizable crossborder bank claims on foreign countries with high domestic crisis risk enable contagion to the home economy. This asset-side channel opposes traditional views that see banking crises originating from either domestic credit booms or from cross-border borrowing. I propose a combined model that predicts banking crises using both domestic and foreign factors. For developed economies, the channel is predictive of crises irrespective of other types of capital flows, while it is entirely inactive for emerging economies. I show that policy makers can significantly enhance current early warning models by incorporating exposure-based risk from cross-border lending.
\end{abstract}

JEL classification: C53, E44, F34, G01, G21.

Keywords: Cross-border bank lending, banking crises, systemic risk, financial linkages.

*John F. Kennedy Institute. E-mail: daniel.dieckelmann@fu-berlin.de. I am grateful for comments and suggestions received from Matthew Baron, Jonathan Benchimol, Natalia Danzer, Astrid Pape, Yossef Saadon, Max Steinhardt, Till Strohsal, and various participants at the Graduate Seminar of the Berlin School of Economics (BSE) and at the Finance department seminar during my stay at the Bank of Israel. Financial support from the Deutsche Forschungsgemeinschaft (DFG) is gratefully acknowledged. An earlier version of this paper was circulated under the title "Cross-Border Claims and Banking Crises: An Early Warning System for Small Open Economies". 


\section{INTRODUCTION}

Over a decade ago, the Global Financial Crisis shook the world economy to its core. From its epicenter in the United States it quickly spread around the globe. While the crisis saw a major part of the developed world economy struggle with systemic banking crises and subsequent political upheaval, a significant number of small open economies weathered the storm with not much more than a scratch (Lane \& Milesi-Ferretti, 2011). These nations had to endure adverse effects due to the subsequent collapse in global trade and economic activity, but a banking crisis itself never reached their domestic banking systems. In this paper, I propose a new channel of international banking crisis transmission that explains the resilience of these small open economies, and develop an early warning model that can help policy makers to account for the systemic risk of banking crises from abroad that arises through this channel. I present a combined model of domestic and exposure-based risk that outperforms traditional approaches both in and out-of-sample.

In contrast to the existing and ample literature on banking crisis transmission, I emphasize a cross-border bank lending channel of contagion that works from banks in countries borrowing money to the banking system in a country that lends to these banks. ${ }^{1}$ When a banking crisis unfolds in a foreign economy to which the home banking system has lent significantly, foreign banks may default on their loans and thus bring home banks into jeopardy. This stands in opposition to the cross-border bank borrowing channel á la Kaminsky \& Reinhart (2000), Schnabl (2012), and Bruno \& Shin (2015), in which banking crises spread from lending countries to recipient countries through a devaluation of the home currency in case the debt is foreign-denominated or through a negative credit supply shock from abroad.

1 Importantly, I confine my analysis to the question of banking crisis incidence. Economies that have no exposure to the proposed channel of crisis propagation may still be affected in the aftermath of a banking crisis abroad when the real side of the economy is affected, and trade and foreign demand are inhibited. This secondary transmission channel is not subject of my study. I am purely interested in how countries are "infected" with banking crises from abroad, which have first-round adverse economic effects on the home economy. Second-round effects may occur additionally when trade with the infecting country collapses due to the banking crisis there. 
Recently, the borrowing channel has been put into question by Karolyi et al. (2018) who find that heightened bank flows are actually associated with improved financial stability in a recipient country's banking system.

Another strand in the literature considers domestic causes of financial instability and sees banking crises as the result of Minskyan domestic boom-bust dynamics. Schularick \& Taylor (2012) among many others have convincingly shown that banking crises are often triggered by credit booms gone bust. The pattern of crisis incidence of the Global Financial Crisis, however, poses a puzzle: Countries without domestic credit booms-like Germany or Switzerland - experienced banking crises, while highly leveraged and capital-importing economies such as Australia or Canada did not. These observations can neither be explained by Minskyan dynamics nor by a bank borrowing channel. This open flank of the financial stability literature is further accentuated by the fact that the role of net financial flows is not clear in explaining banking crises: The current account balance is an ambiguous crisis predictor (Frankel \& Saravelos, 2012; Kauko, 2014). In this study, I resolve the puzzle through the introduction of the cross-border bank lending channel, and I further shed light on the role of the current account.

To show how the asset-side exposure to a foreign banking system functions as a channel of contagion, I develop a model that combines domestic risk of banking crisis with exposurebased risk. The domestic model uses standard multivariate logistic regressions with a binary banking crisis classifier as dependent variable and a set of macro-financial indicators as independent variables. The exposure-based model employs a weighted sum of domestic crisis probabilities in foreign countries on which the home economy has bank claims. As weights, I use the volume of the home country's cross-border asset-side exposure in relation to the size of its economy. The estimated crisis probabilities are measured against a threshold value that minimizes a loss function which considers the policy maker's preference for type I over type II errors (Detken et al., 2014). Whenever the threshold is breached a warning signal is issued. 
I find that economies with low domestic financial risk still experienced banking crises at home if their banking system had accumulated large claims (in terms of GDP) towards banks in countries with high domestic risk. Conversely, some small open economies with elevated domestic instability demonstrated resilience because their banking systems had not lent heavily to banks in other high-risk countries. Combining both approaches significantly enhances the predictive ability of a model that considers domestic risks alone and showcases the significance of cross-border bank lending as a mechanism of crisis transmission. The combined system is tested in a recursive out-of-sample setting and outperforms both individual models.

To the best of my knowledge, this study is the first to propose an asset-side channel of banking crisis transmission and reverse the direction of the liability-side channel that has been prevalent in the literature. Methodologically, I build on the pioneering work of Lang (2018) who recently introduced exposure-weighted foreign variables into a multivariate logistic regression model set-up. The contributions of this paper are highly relevant for policy makers as the combined model laid out here significantly enhances their monitoring abilities of systemic risk built-up by factoring in domestic risks abroad and weighing it with their home banking system's asset-side exposure to these risks.

Relatively few studies have previously integrated financial linkages into an early warning setting. Rose \& Spiegel (2010) model both national and international causes of the Global Financial Crisis within a multiple indicator multiple cause model. The international aspect is characterized by a real channel that consists of trade linkages and by a financial channel that reflects exposure to U.S. (or other high-risk countries') assets. The authors find little evidence, however, that either of the international factors matter in predicting the difference in crisis incidence. Minoiu et al. (2015), on the other hand, find that financial interconnectedness is a useful early warning indicator. The authors employ a classifications algorithm on network connectedness measures to predict systemic banking crises. They find that a country's own higher connectedness and lower connectivity among its direct financial partners 
both predict higher crisis probabilities. A binary regression model that includes connectivity measures outperforms a model that uses domestic macroeconomic factors alone. Aldasoro et al. (2018) add a total cross-border claims-to-GDP ratio to a set of credit and asset price indicators and find that it improves the predictive capabilities of a standard early warning model of banking crises. The ratio's predictive power intensifies the closer the forecasting horizon is set to the crisis event. The cross-border claims fare better than foreign-currency debt as ab indicator which underlines the importance of considering the role of international lending as opposed to international borrowing in propagating banking crises.

The remainder of the paper is structured as follows. The upcoming section describes the proposed transmission channel in detail and presents supporting stylized facts. Section three discusses the data set and explains the methodology. Section four presents the main results, both in-sample and out-of-sample. In section five, I discuss crisis incidence and the role of cross-border bank lending during the Global Financial Crisis. I conclude and offer policy advice in section six.

\section{CROSS-BORDER BANK LENDING AND BANKING CRISES}

Banking crises generally arise from two different origins: economic and financial imbalances in the domestic economy, or disturbances abroad that are transmitted to the home economy. I refer to the latter channel broadly as contagion or the international transmission of banking crises. In their seminal study, Kaminsky \& Reinhart (2000) distinguish between two types of linkages with two different channels each, through which financial crises can transmit from abroad to the home economy. ${ }^{2}$ Figure 1 summarizes the taxonomy of transmission channels and places the new lending channel (marked in light grey) within that framework.

First, trade linkages between countries facilitate the propagation of shocks either through

2 I distinguish between a financial crisis and a banking crisis in so far as that the latter is a sub-category of the former. I follow Claessens \& Kose (2013) and distinguish between banking crises, currency crises, sudden stops, and debt crises. Importantly, I do not discuss the incidence of currency crises in this paper as long as they do not coincide with a banking crises (twin crises). 
Figure 1: Channels of international banking crisis transmission.

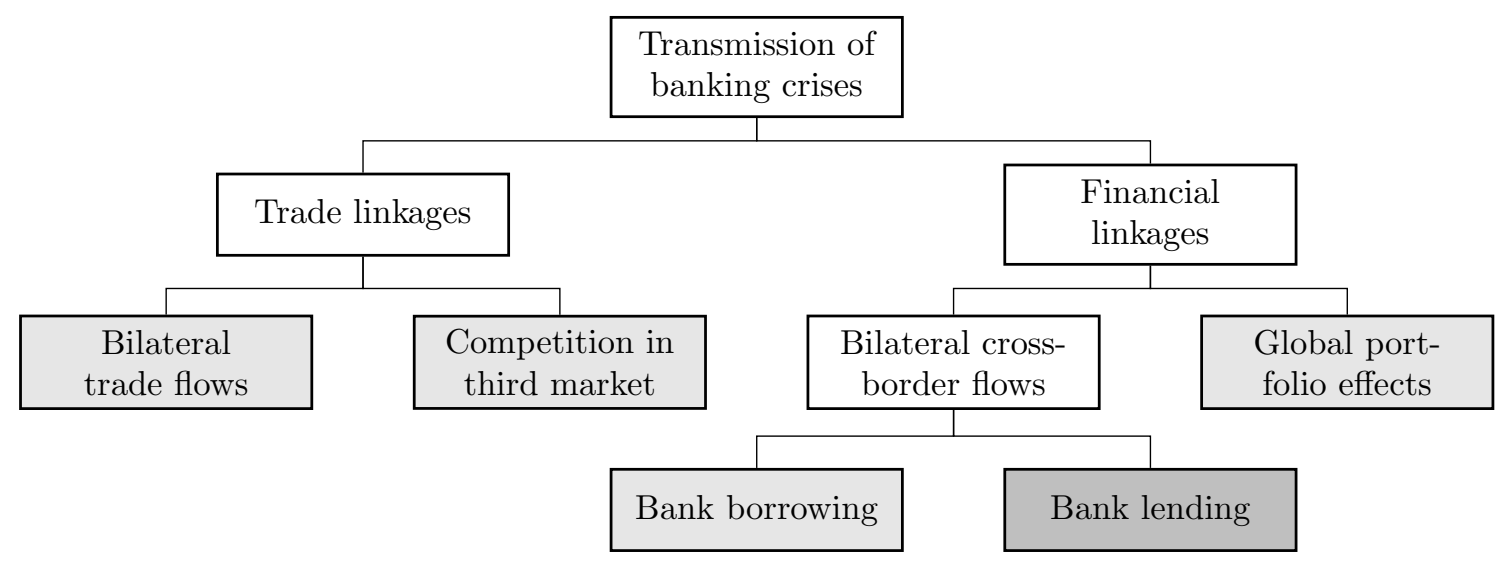

bilateral trade exposure or through competition in a common third market. Direct bilateral trade links matter in terms of contagion especially after a crisis unfolded in the foreign economy. The consequential downturn in economic activity abroad depresses demand for export goods at home and weakens the domestic real economy to the extend that it might bring banks at home in danger, potentially triggering a banking crisis at home. The second channel involves competition between the foreign and home country in a common third country and is based on a story of competitive devaluation. In case a banking crisis develops in the foreign economy its currency will devalue making its goods cheaper vis-à-vis the third country. The home country, which competes with the foreign economy in exports for the same good to the third country, may choose to devalue its own currency to remain competitive. This devaluation may bring banks at home into jeopardy that previously had borrowed heavily in foreign currency as they will find it much harder to repay their outstanding debts, potentially triggering a domestic banking crisis.

Second, less well-studied financial linkages enable the transmission of crises either through bilateral cross-border bank flows or through global portfolio effects. The currency crisis literature has long emphasized a channel of contagion through bilateral cross-border flows from a foreign country lending significant funds denominated in the foreign currency to the home economy (Kaminsky \& Reinhart, 1999). More recently, Schnabl (2012) and Bruno \& Shin 
(2015) have confirmed contagion from a foreign, lending economy to a domestic, borrowing banking system as the direction of effect. Karolyi et al. (2018), however, revisit this channel and find that sizable flows from foreign to home banks actually increase financial stability in the recipient country. In this study, I reverse the direction of the bilateral cross-border flow channel and hypothesize a bank lending channel through which banking crises are transmitted from a foreign, borrowing economy to the domestic, lending economy. The global portfolio channel, lastly, refers to the exchange of non-bank financial assets across borders. While a foreign country experiencing a banking crisis will likely be affected by massive sales of its financial assets due to its deteriorating economic prospects, third-party international investors may be liquidity-constrained such that they may be unable to sell foreign assets at a price sufficient for meeting their cash flow requirements and may thus be forced to sell assets of the home economy, which they hold on their balance sheets, to free up cash. This will depress prices at home and could lead to a significant weakening of domestic banks' balance sheets, increasing the probability of a banking crisis at home.

Figure 2: The cross-border bank lending channel

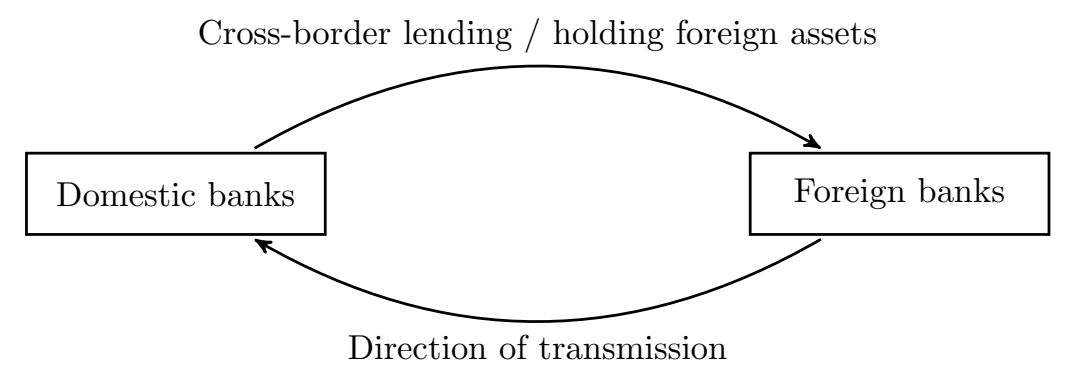

In this study, I focus narrowly on the cross-border bank channel and specifically introduce an asset-side view of cross-border bank lending to the well-developed literature on contagion that focuses entirely on (foreign-denominated) cross-border bank borrowing (from the perspective of the infected or home country). It is important to note that, from an accounting perspective, outstanding loans to abroad on a domestic bank's balance sheet are equivalent to holding liabilities of foreign banks, such as mortgage backed securities, at home 
or maintaining deposits at banks abroad - they all show up as positions on the asset-side of the domestic bank owed to a foreign entity. This is why I occasionally refer to the bank lending channel more generally as the asset-side channel of cross-border banking. Figure 2 illustrates the channel and the direction of ts effect.

Theoretically, the cross-border bank lending channel can be decomposed into three subchannels which each explain a distinct process of how a banking crisis can be triggered in the home country when a foreign economy, to which the home country has lent heavily, experiences a banking crisis itself. First, a banking crisis in the foreign economy could cause foreign banks to go bankrupt which then would default on their international liabilities, bringing the banks in the home economy into jeopardy and potentially triggering a banking crisis at home. Second, foreign banks may remain solvent but find themselves unable to access liquidity because of a banking panic or general loss in confidence. The foreign banks may find it difficult to acquire the liquidity to pay back the loans they owe to the home country's banking system thereby inducing financial instability at home. Third, depressed real economic activity abroad resulting from a banking crisis (i.e. second-round effect) lowers the demand for credit in the home economy which previously had lent heavily to the now adversely affected foreign economy. This could endanger home banks' profitability and increase the probability of banking crisis at home.

While the Global Financial Crisis of the last decade wreaked economic havoc around the globe, there were important differences in crisis incidence among developed and emerging economies as well as between them (Rose \& Spiegel, 2011; Lane \& Milesi-Ferretti, 2011; Berkmen et al., 2012). A closer look at the developments following the crisis reveals that some countries fared remarkably well despite the sudden halt in global trade and the severe disruptions in international financial markets. Australia, Canada, Chile, the Czech Republic, Israel, New Zealand, and Poland were among these resilient economies which did not experience systemic banking crises at home and also exhibited considerably lower output losses. Contrarily, the U.S. subprime crisis triggered systemic banking crises in Denmark, 
Germany, Hungary, Norway, Spain, Sweden, and Switzerland, among others. ${ }^{3}$

The Minsky-Kindleberger-Fisher boom-bust narrative (Minsky, 2008; Kindleberger \& Aliber, 2015; Fisher, 1933) has been prevalent in the discussion of the Global Financial Crisis (e.g. Schularick \& Taylor, 2012; Eggertsson \& Krugman, 2012; Brunnermeier \& Sannikov, 2014) but cannot sufficiently explain the observed crisis incidence. Countries like Australia and Canada were domestically highly leveraged, exhibited house price hikes but did not experience banking crises, while unleveraged economies with flat property price developments like Switzerland and Germany suffered from systemic bank failures and saw government-led bailouts. I address this deficiency by augmenting the story of domestic built-up of imbalances by an approach that incorporates the transmission of systemic risk from abroad. Figure 3 illustrates this exposure-based view by depicting bilateral cross-border bank claims in relation to GDP among several important economies at the onset of the recent crisis in the first quarter of 2007. The displayed weights are calculated as

$$
w_{i}^{j}=\frac{\text { bank claims }_{i}^{j}}{\mathrm{GDP}_{i}}
$$

where bank claims ${ }_{i}^{j}$ are the bank claims of home country $i$ on the foreign economy $j .{ }^{4}$ This exposure measure is then divided by the home country's GDP. In short, the figure displays a home economy's cross-border exposure against foreign countries in relation to its GDP. During the estimation process of the exposure-based model the weights are then further multiplied by the foreign countries' estimated domestic crisis probability to retrieve an exposure-based index of foreign-induced risk of financial instability. Grey fields in the figure indicate the non-availability of data.

The central role of London as a center of global finance is immediately visible from the prominent position of Great Britain as a counterparty with which many economies main-

3 A structured approach to dating and identifying historical banking crises is discussed in the next section. 4 As is described in more detail in the following section, these bank claims of country $i$ are often approximated through the liability-side of counterparty countries $\{1, \ldots, J\}$ as not all countries in the sample report their cross-border exposures. 
Figure 3: Cross-border claims at the onset of the Global Financial Crisis

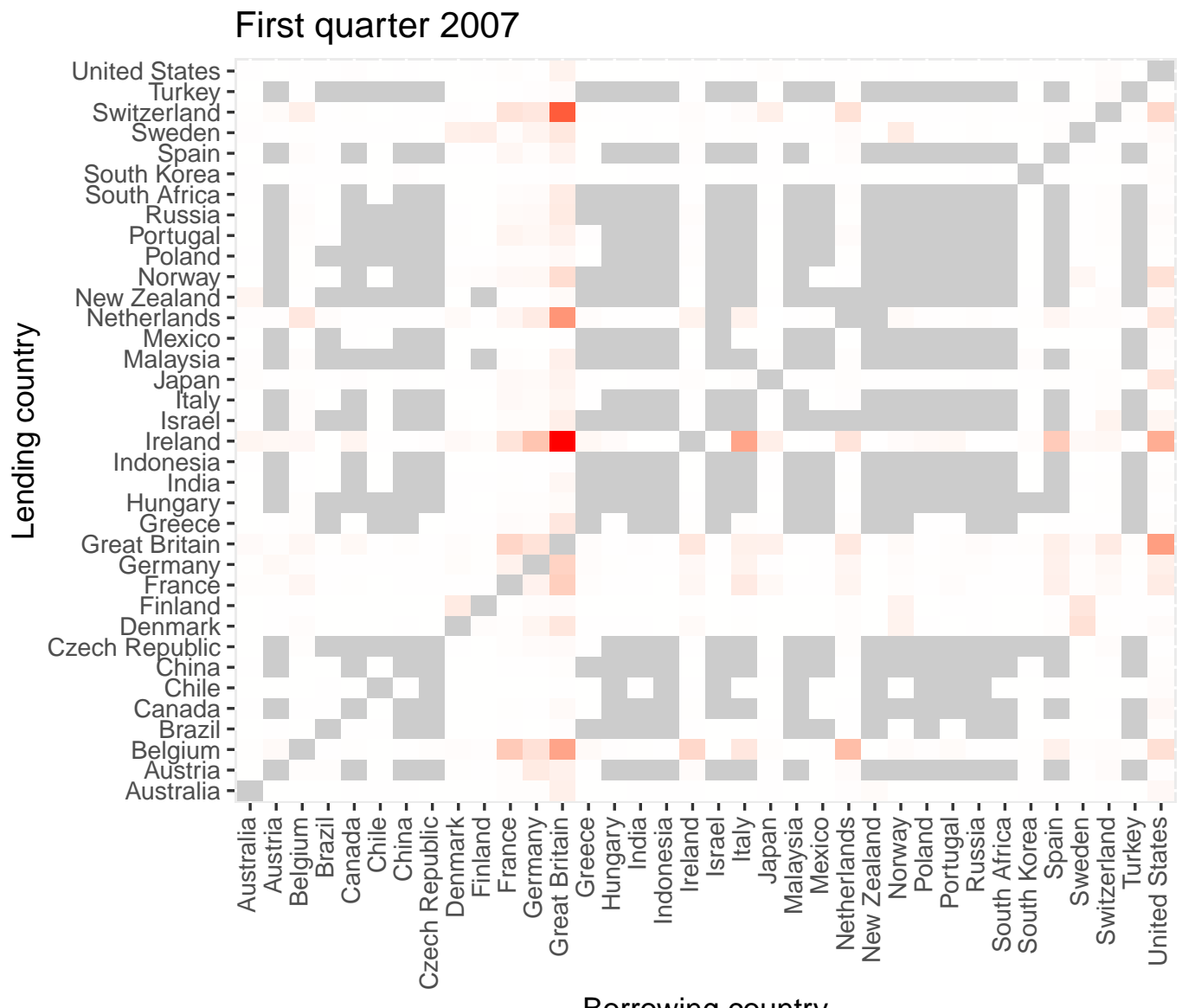

Borrowing country

\section{Lending country's bank claims-to-GDP ratio}

0.000 .250 .500 .75

tain high levels of cross-border exposure. This exposure can take various, such as loans to, deposits at, or financial assets emitted by British banks. Switzerland, the Netherlands, Ireland, and - to a lesser extend - Belgium and Norway exhibit high levels of exposure to Great Britain. All these nations were subsequently hit by domestic banking crises. Paradoxically, the direct exposure of these countries to the United States did not seemed to have mattered as much. The exposure of Great Britain, in turn, to the United States was substantial. This stylized fact gives a first impression of how the crisis may have spread from the United States to the British Banking System and from there to various developed economies in relative close geographical proximity. On the other hand, countries like Canada, Australia, Israel, or 
New Zealand were not exposed to British assets and-due to the resulting unimportance of the asset-side transmission channel - did not experience banking crises at home, either.

Irrespective of to their domestic macro-financial conditions some countries effectively were financial islands in the storm that was the recent crisis, because they maintained no significant exposures to the U.S. subprime market or to third countries that themselves had significant exposures and turned out to developed their own banking crises. ${ }^{5}$ In the following section, I propose a methodology to combine the domestic risk of banking crisis with the exposure-based risk of being subject to destabilizing spill-over effects from abroad.

\section{Methodology AND DATA}

My general idea to show that the cross-border bank lending channel matters for the transmission of banking crises is to factor in exposure-based risk into a model that otherwise only considers domestic imbalances as a source of financial instability. I expect this combined model to clearly outperform a purely domestic one in predicting banking crises as it additionally considers the risk of instability that stems from abroad. Taken to the historical data, the combined model should further be able to predict the incidence of banking crises in individual countries during the recent global crisis period out-of-sample.

I compute three distinct models: A domestic model (DM), an exposure-based model (EM), and a combined model (DEM). The general approach of all three models closely follows the established early-warning literature. ${ }^{6}$ This proximity is important since the model can be useful for policy makers wishing to enhance current approaches to predicting banking crises. All three models produce probability estimates and a corresponding threshold value that emits a warning signal of imminent crisis when it is breached. The DM uses standard

5 It is interesting to note that many of the developed economies that proved resilient are those that have a consistent and long history of remarkable financial stability. The question whether the asset-side channel could also be helpful in explaining why banking systems in Canada, New Zealand, or Australia were historically largely resistant to contagion I leave for future research.

6 Frankel \& Saravelos (2012) and Kauko (2014) provide excellent literature overviews and comprehensive reviews of the predictive power of various banking crisis indicators. 
Table 1: Data availability and crisis observations

\begin{tabular}{|c|c|c|c|c|c|c|c|c|}
\hline \multirow[t]{2}{*}{ Country } & \multicolumn{2}{|c|}{ Size } & \multicolumn{2}{|c|}{ Type } & \multirow{2}{*}{$\begin{array}{c}\text { Indicator Data } \\
\text { Start }\end{array}$} & \multirow{2}{*}{$\begin{array}{c}\text { LBS data } \\
\text { Start }\end{array}$} & \multicolumn{2}{|c|}{ Banking crises } \\
\hline & Small & Large & Emerg. & Dev. & & & Start & End \\
\hline Australia & $\mathrm{X}$ & & & $\mathrm{X}$ & 1974q1 & $1977 q 4$ & 1990q1 & $1992 q 1$ \\
\hline Austria & $\mathrm{X}$ & & & $\mathrm{X}$ & $2003 \mathrm{q} 1$ & $1977 \mathrm{q} 4$ & $2008 \mathrm{q} 3$ & $2011 \mathrm{q} 4$ \\
\hline Belgium & $\mathrm{X}$ & & & $\mathrm{X}$ & 1995q1 & $1977 q 4$ & $2008 \mathrm{q} 3$ & $2009 \mathrm{q} 4$ \\
\hline Brazil & & $\mathrm{X}$ & $\mathrm{X}$ & & $2004 q 1$ & 1996q1 & $\begin{array}{l}1985 q 3 \\
1994 q 3\end{array}$ & $\begin{array}{l}1986 \mathrm{q} 4 \\
1997 \mathrm{q} 4\end{array}$ \\
\hline Canada & $\mathrm{X}$ & & & $\mathrm{X}$ & 1973q1 & $1977 q 4$ & $1982 q 3$ & $1985 \mathrm{q} 4$ \\
\hline Chile & $\mathrm{X}$ & & $\mathrm{X}$ & & $2005 \mathrm{q} 1$ & $1983 q 1$ & $\begin{array}{l}1975 \mathrm{q} 2 \\
1981 \mathrm{q} 3\end{array}$ & $\begin{array}{l}1977 \mathrm{q} 4 \\
1984 \mathrm{q} 4\end{array}$ \\
\hline China & & $\mathrm{X}$ & $\mathrm{X}$ & & $2008 \mathrm{q} 2$ & $1985 \mathrm{q} 4$ & $1998 \mathrm{q} 1$ & $1998 \mathrm{q} 4$ \\
\hline Czech Republic & $\mathrm{X}$ & & $\mathrm{X}$ & & 2011q1 & $1993 q 4$ & $\begin{array}{l}1994 \mathrm{q} 2 \\
2000 \mathrm{q} 2\end{array}$ & $\begin{array}{l}1999 q 1 \\
2001 q 4\end{array}$ \\
\hline Denmark & $\mathrm{X}$ & & & $\mathrm{X}$ & 1993q1 & $1977 q 4$ & $\begin{array}{l}1992 q 2 \\
2008 \mathrm{q} 3\end{array}$ & $\begin{array}{l}1995 q 1 \\
2013 q 4\end{array}$ \\
\hline Finland & $\mathrm{X}$ & & & $\mathrm{X}$ & $1975 q 1$ & $1977 \mathrm{q} 4$ & 1991q3 & $1994 \mathrm{q} 2$ \\
\hline France & & $\mathrm{X}$ & & $\mathrm{X}$ & 1995q1 & $1977 \mathrm{q} 4$ & $\begin{array}{l}1991 q 3 \\
2008 \mathrm{q} 3\end{array}$ & $\begin{array}{l}1995 q 1 \\
2009 q 4\end{array}$ \\
\hline Germany & & $\mathrm{X}$ & & $\mathrm{X}$ & 1973q1 & $1977 q 4$ & $2008 \mathrm{q} 3$ & $2010 \mathrm{q} 2$ \\
\hline Great Britain & & $\mathrm{X}$ & & $\mathrm{X}$ & $1977 \mathrm{q} 4$ & $1977 q 4$ & $\begin{array}{l}1973 \mathrm{q} 1 \\
1991 \mathrm{q} 3 \\
2008 \mathrm{q} 3\end{array}$ & $\begin{array}{l}1975 \mathrm{q} 4 \\
1994 \mathrm{q} 2 \\
2011 \mathrm{q} 4\end{array}$ \\
\hline Greece & $\mathrm{X}$ & & $\mathrm{X}$ & & $2013 \mathrm{q} 1$ & $1977 q 4$ & $2011 \mathrm{q} 3$ & $2014 q 4$ \\
\hline Hungary & $\mathrm{X}$ & & $\mathrm{X}$ & & $2010 \mathrm{q} 4$ & $1977 \mathrm{q} 4$ & $\begin{array}{l}\text { 1991q1 } \\
\text { 1997q1 } \\
2008 \mathrm{q} 3\end{array}$ & $\begin{array}{l}1995 \mathrm{q} 4 \\
1997 \mathrm{q} 4 \\
2010 \mathrm{q} 3\end{array}$ \\
\hline Ireland & $\mathrm{X}$ & & & $\mathrm{X}$ & 1990q1 & $1977 q 4$ & $\begin{array}{l}2008 \mathrm{q} 3 \\
2010 \mathrm{q} 4\end{array}$ & $\begin{array}{l}2009 \mathrm{q} 4 \\
2012 \mathrm{q} 4\end{array}$ \\
\hline Israel & $\mathrm{X}$ & & & $\mathrm{X}$ & 1997q1 & $1990 \mathrm{q} 4$ & $1983 q 4$ & $1985 \mathrm{q} 4$ \\
\hline Italy & & $\mathrm{X}$ & & $\mathrm{X}$ & $1988 \mathrm{q} 1$ & $1977 q 4$ & $\begin{array}{l}1991 \mathrm{q} 3 \\
2011 \mathrm{q} 3 \\
2016 \mathrm{q} 1\end{array}$ & $\begin{array}{l}1995 \mathrm{q} 1 \\
2013 \mathrm{q} 4 \\
2019 \mathrm{q} 4\end{array}$ \\
\hline Japan & & $\mathrm{X}$ & & $\mathrm{X}$ & $1985 \mathrm{q} 1$ & $1977 q 4$ & $\begin{array}{l}1990 \mathrm{q} 3 \\
1997 \mathrm{q} 4 \\
2001 \mathrm{q} 2\end{array}$ & $\begin{array}{l}1996 \mathrm{q} 4 \\
2000 \mathrm{q} 4 \\
2005 \mathrm{q} 2\end{array}$ \\
\hline Mexico & & $\mathrm{X}$ & $\mathrm{X}$ & & $2008 \mathrm{q} 1$ & $1980 \mathrm{q} 4$ & $\begin{array}{l}1982 \mathrm{q} 3 \\
1994 \mathrm{q} 4\end{array}$ & $\begin{array}{l}1982 \mathrm{q} 4 \\
1997 \mathrm{q} 4\end{array}$ \\
\hline Netherlands & $\mathrm{X}$ & & & $\mathrm{X}$ & $1982 q 1$ & $1977 q 4$ & $2008 \mathrm{q} 3$ & $2009 \mathrm{q} 2$ \\
\hline New Zealand & $\mathrm{X}$ & & & $\mathrm{X}$ & $1987 \mathrm{q} 1$ & $1977 \mathrm{q} 4$ & $1988 \mathrm{q} 3$ & $1990 \mathrm{q} 4$ \\
\hline Norway & $\mathrm{X}$ & & & $\mathrm{X}$ & $1994 q 3$ & $1977 q 4$ & $\begin{array}{l}1991 \mathrm{q} 4 \\
2008 \mathrm{q} 3\end{array}$ & $\begin{array}{l}1994 q 2 \\
2009 q 4\end{array}$ \\
\hline Poland & $\mathrm{X}$ & & $\mathrm{X}$ & & 2013q1 & 1992q1 & 1992q1 & $1996 \mathrm{q} 4$ \\
\hline Portugal & $\mathrm{X}$ & & & $\mathrm{X}$ & $2013 \mathrm{q} 1$ & $1977 q 4$ & $2008 \mathrm{q} 3$ & $2012 \mathrm{q} 4$ \\
\hline Russia & & $\mathrm{X}$ & $\mathrm{X}$ & & $2004 \mathrm{q} 1$ & $1995 \mathrm{q} 2$ & $\begin{array}{l}1995 \mathrm{q} 3 \\
1998 \mathrm{q} 3 \\
2008 \mathrm{q} 3\end{array}$ & $\begin{array}{l}1995 \mathrm{q} 4 \\
1999 \mathrm{q} 4 \\
2009 \mathrm{q} 4\end{array}$ \\
\hline South Africa & & $\mathrm{X}$ & $\mathrm{X}$ & & $1969 \mathrm{q} 1$ & $1977 q 4$ & & \\
\hline South Korea & & $\mathrm{X}$ & $\mathrm{X}$ & & $1984 \mathrm{q} 1$ & $1977 \mathrm{q} 4$ & $1997 q 4$ & $1998 \mathrm{q} 4$ \\
\hline Spain & & $\mathrm{X}$ & & $\mathrm{X}$ & 1990q1 & $1977 q 4$ & $\begin{array}{l}1978 \mathrm{q} 1 \\
2008 \mathrm{q} 3\end{array}$ & $\begin{array}{l}1981 q 4 \\
2012 q 4\end{array}$ \\
\hline Sweden & $\mathrm{X}$ & & & $\mathrm{X}$ & $1982 q 1$ & $1977 q 4$ & $\begin{array}{l}1992 \mathrm{q} 3 \\
2008 \mathrm{q} 3\end{array}$ & $\begin{array}{l}1997 \mathrm{q} 2 \\
2009 \mathrm{q} 2\end{array}$ \\
\hline Switzerland & $\mathrm{X}$ & & & $\mathrm{X}$ & $1973 \mathrm{q} 1$ & $1977 q 4$ & $\begin{array}{l}1992 q 3 \\
2008 \mathrm{q} 3\end{array}$ & $\begin{array}{l}1997 q 2 \\
2009 q 2\end{array}$ \\
\hline Turkey & & $\mathrm{X}$ & $\mathrm{X}$ & & 2013q1 & $1986 \mathrm{q} 1$ & $\begin{array}{l}1983 q 4 \\
1994 \mathrm{q} 2 \\
2000 \mathrm{q} 4\end{array}$ & $\begin{array}{l}1984 \mathrm{q} 4 \\
1994 \mathrm{q} 4 \\
2001 \mathrm{q} 4\end{array}$ \\
\hline United States & & $\mathrm{X}$ & & $\mathrm{X}$ & $1973 \mathrm{q} 1$ & $1977 q 4$ & $\begin{array}{l}1984 \mathrm{q} 1 \\
1991 \mathrm{q} 1 \\
2007 \mathrm{q} 3\end{array}$ & $\begin{array}{l}1986 \mathrm{q} 4 \\
1992 \mathrm{q} 2 \\
2010 \mathrm{q} 4\end{array}$ \\
\hline
\end{tabular}

Notes: The start date for indicator data refers to the first date for which all indicators are available for model estimation. The start date for LBS data refers to the first data for which either LBS asset-side data is available or for which asset-side data can be proxied by liability data of reporting counterparties. Emerg. refers to emerging economy. Dev. refers to developed economy. 
multivariate logistic regressions with a binary banking crisis classifier as dependent variable and a set of macro-financial indicators as independent variables. The EM employs the GDPweighted sum of domestic crisis probabilities in foreign countries on which the home economy has bank claims. Effectively, the EM measures a home country's exposure to risk of banking crisis in foreign countries based on the size of claims the home country's banking system maintains with these foreign countries. The home country's exposure to each foreign country is then multiplied by the foreign country's own estimated domestic crisis probability. Lastly, The DEM includes the weighted foreign risk measure into the logistic regression equation of the DM. The estimated crisis probabilities of all models are measured against respective threshold values that minimize a loss function which considers the policy maker's preference for type I over type II errors. Whenever a threshold is breached a warning signal is issued.

The dataset consists of two components: first, an unbalanced panel of national macrofinancial variables and banking crisis observations, and second, a network of cross-border bank assets and liabilities. The data have quarterly frequency and coverage begins in the 1970s for major countries and ends with the second quarter of 2019. Table 1 gives a comprehensive overview of data availability and banking crisis dates. The national macro-financial variables come from the OECD and the BIS. Banking crisis dates are determined by a structural and quantitative approach based on bank stock price data, as discussed in the following section. The cross-border banking data is calculated from the Locational Banking Statistics (LBS) published by the BIS. Unfortunately, not all nations report their asset-side crossborder exposure to the LBS. For countries which do not, the exposure is approximated by the liability-side of their counterparties that do report.

The total panel includes 33 countries. To ensure data availability and quality at quarterly frequency, all nations are either members, accession candidates, or key partners of the OECD and report their national data to the organization. Selecting the countries poses a challenge as the results of this study shall be generalizable. I, thus, aim to include all major developed economies and further all nations large enough to function as key influen- 
tial players either globally or locally (i.e. the United States, Japan, and China). A second consideration is to balance developed with emerging economies, larger with smaller nations, and account for geographical variation, as well. Nations I would have liked to include but for which I had difficulties to obtain correct data at a high enough frequency were Hong Kong and Singapore (regional financial centers); Iceland (highly exposed prior to the recent crisis); and Colombia and Argentina (virtually unaffected by the Global Finanical Crisis).

I categorize economies as large if their population exceeds 50 million, and as small otherwise. I am interested in investigating whether the impact of the cross-border bank lending channel on financial instability differs from smaller countries to larger ones. It is conceivable that smaller economies may face a bigger threat from foreign exposure as their financial systems might quickly outgrow the size of their domestic economies like in Iceland, Ireland, Switzerland, or Luxembourg. Conversely, larger economies are more likely to have a high number of internationally active banks which would increase their crossborder exposure in relation to smaller, non-international banking systems. I further define two country subsets of emerging and developed economies for which I use the classification of major finance company MSCI that is common in financial market practice. ${ }^{7}$ Since the currency crisis literature has long stressed - what I call-the cross-border bank borrowing channel of crisis transmission, i.e. through the exposure to foreign(-denominated) liabilities, I investigate whether the asset-side (or lending) channel also applies to emerging economies or is rather a phenomenon of more developed economies. I estimate all models separately for the four country subsets and once for the entire sample.

\footnotetext{
7 https://www.msci.com/market-classification, accessed January 2020. Israel was moved into the developed economy category in 2010. Classifying Israel for the purpose of this paper instead as an emerging economy reduces the size of the standard errors for the emerging market subset somewhat but does not alter the general results - neither in terms of sign or of significance of the estimated coefficients.
} 


\section{DATING BANKING CRISES}

A binary dummy serves as the independent variable of all three models and is set to one whenever a systemic banking crisis is ongoing in a specific country at a specific point in time, and to zero otherwise. The identification and dating of banking crises is no easy matter and lively discussions have revolved around the correct methodology. Thus, several competing databases exist (Demirgüç-Kunt \& Detragiache, 1998; Kaminsky \& Reinhart, 1999; Bordo et al., 2001; Reinhart \& Rogoff, 2009; Jordà et al., 2017; Lo Duca et al., 2017; Romer \& Romer, 2017; Laeven \& Valencia, 2018). Recently, Baron et al. (2020) have proposed a promising method to consolidate and restructure these often narrative-based approaches and introduced a novel dataset of historical bank stock prices for 46 countries over the past 150 years to date periods of bank distress. Whenever a country's bank stock index drops by at least 30 percent the event is considered, and the literature is systemically scanned for evidence of widespread bank failures and panics, i.e. bank runs or heavy disturbances in the interbank market. With this approach the authors are able to detect previously unknown crisis episodes, confirm well-known events, and discard several spurious crises that were prominent in the literature but otherwise left little evidence in the data. Based on Baron et al. (2020), Baron \& Dieckelmann (2020) build a comprehensive database of banking crises that extends the current dataset by adding post-crisis GDP, bank credit, and public debt measures; by quantifying policy responses, such as liquidity provision, bank holidays, liability guarantees, or bank nationalizations; and by providing narrative summaries for more than 150 bank distress events.

In this study, I build on the advanced crisis dating methodology of the forthcoming database. Specifically, I employ a three-step process to identify periods of significant bank distress and date the quarter of their beginning and end. First, I select all events from the database that are identified to have exhibited widespread bank failures. Widespread, hereby, is defined as either more than five banks or at least one major bank. Second, I choose 
the quarter in which a panic occurred as the starting date for these distress episodes. The panic date refers to the month in which bank runs, the collapse of interbank markets, or the failure of a systemic institution occurred. Not all periods of widespread bank failures exhibit a panic. These episodes Baron et al. (2020) call "quiet crises" because they are often resolved without much knowledge of the public, but still can - as the authors showsignificantly impair economic activity. Third, if no panic is recorded, I resort to the excellent databases of Laeven \& Valencia (2018) and Lo Duca et al. (2017) as they offer precise dating of the beginning, and in the latter case, of the end of distress periods. In the rare case that the two sources do not agree with Baron \& Dieckelmann's (2020) dating method and do not record dates for the respective events, I use the quarter in which the bank stock prices drop by at least 30 percent as the starting date of the crisis. Table A.9 in the appendix illustrates the result of the dating process in detail.

\section{THE DOMESTIC MODEL}

To predict the probability of a banking crisis resulting from domestic imbalances, I choose a standard method - a pooled multivariate logistic regression model - from the tool set of the early warning literature to ensure economic interpretatability and tractability. First, I define a baseline model of the form

$$
\operatorname{logit}\left(\pi^{d}\right)=\ln \frac{\pi^{d}}{1-\pi^{d}}=\beta_{0}+\beta_{1} X+\epsilon
$$

where $\pi^{d}$ is the probability of occurrence of a banking crisis within a certain range of upcoming quarters, called pre-crisis horizon. ${ }^{8} X$ is a vector of independent variables. I evaluate the estimated probability $\hat{\pi^{d}}$ against a threshold value. If $\hat{\pi^{d}}$ breaches that threshold a warning signal is issued. For readability, time indexes are dropped from the notation above. The pre-crisis horizon is set to a range of 3 to 12 quarters and is motivated by the stylized facts

8 Strictly speaking, I am not predicting crisis observations but pre-crisis periods. The idea here is to give governments and monetary authorities sufficient time to react to an impending crisis. 
provided further below in Figure 4 where credit growth tends to peak between three to five quarters before a crisis and house prices peak earlier at around eight to twelve quarters prior. This range is also well in line with pre-crisis horizons set by Holopainen \& Sarlin (2017, five to twelve quarters) and Detken et al. (2014, four to twenty quarters). ${ }^{9}$

Bussiere \& Fratzscher (2006) report the existence of a post-crisis bias when observations enter the model estimation process at time points when crises are unfolding (crisis periods) or being resolved (post-crisis periods). Including these observations can distort model results as they present states of the economy where adjustment processes are taking place and macrofinancial indicators are thus severely distorted. I account for the post-crisis bias by dropping crisis observations from the training data set. I ensure that crisis periods are dated in such a way that a crisis is considered to be over only when the respective economy has re-entered its normal state. I can thus forgo defining a special post-crisis horizon.

Table 2: Confusion matrix

\begin{tabular}{lcc}
\hline & Crisis & No crisis \\
\hline Signal & True positive & False positive (type I) \\
No signal & False negative (type II) & True negative \\
\hline
\end{tabular}

To assess the model's predictive abilities, I define a confusion matrix as depicted in Table 2 where the occurrence of a crisis 3 to 12 quarters after a signal has been issued is counted as a true positive; and as a false positive if no crisis follows. Equally, if no crisis occurs 3 to 12 quarters after no signal has been issued (the default) the count of true negatives is increased by one. If, however, an unforeseen crisis ensues, a false negative is recorded. Whenever the estimated crisis probability breaches a certain optimal threshold, a warning signal is issued. Next, I construct a linear grid of $n=1000$ evenly distributed possible threshold values $v \in[0,1]$ and loop through all potential threshold values to find the one value that

\footnotetext{
9 Altering the pre-crisis horizon within four years prior to crisis events does not significantly alter the results presented in the next section. It is important, however, to set the horizon long enough to account for the lead peak of house and share prices over private credit. An upper bound of less than ten quarters has proven to be insufficient.
} 
minimizes Alessi \& Detken's (2011) policy maker's loss function of the form

$$
L=\phi \underbrace{\frac{F N}{T P+F N}}_{\text {type II error rate }}+(1-\phi) \underbrace{\frac{F P}{F P+T N}}_{\text {type I error rate }}
$$

where $T P$ and $F P$ are the total number of true and false positives over the entire sample given a certain threshold $v$, and $T N$ and $F N$ are the total number of true and false negatives, respectively. The policy maker sets $\phi \in(0,1)$ according to her preference for issuing a false alarm over missing a crisis without an alarm. $\phi$ thus represents the model's sensitivity to issue a warning signal. A higher value of $\phi$ will result in a more conservative prediction result that prefers a wrong signal over missing a crisis. The choice of the policy parameter influences how low or high the threshold bar will be set. Whether a domestic crisis probability of $p^{d}$ is tolerable or is a reason for concern ultimately depends on the policy maker's risk aversion and policy preference.

I collect five common macro-financial indicators as independent variables for the domestic model that are endorsed by the literature: Total private credit to the non-financial sector, the private debt-to-GDP ratio, residential property prices, stock prices, and the current account-to-GDP ratio. ${ }^{10}$

Table 3: Independent variables

\begin{tabular}{lll}
\hline Indicator & Transformation & Source \\
\hline Private credit to the nonfinancial sector & 3-year real growth rate & BIS \\
Private credit to the nonfinancial sector & to-GDP ratio & BIS \\
Residential property price index & 3-year real growth rate & BIS \\
Equity price index & 3-year real growth rate & OECD \\
Current account balance & to-GDP ratio & OECD \\
\hline
\end{tabular}

The independent variables receive several transformations that are motivated by stylized facts and findings of other studies. According to a now rich literature, financial instability is

${ }^{10}$ I have also used a larger set of indicators including inflation, policy rate, U.S. dollar exchange rate, and government debt. The qualitative results of this study - especially with regard to the functioning of the cross-border lending channel-remain unchanged, however. 
connected to medium-term cycles in private credit and asset prices whose peaks are closed related to and predictive of financial crises (e.g. Borio \& Lowe, 2002; Drehmann et al., 2012; Aikman et al., 2015; Strohsal et al., 2015). It has thus become a standard approach in the early warning literature to extract a medium-term deviation from trend from private credit and asset prices to capture the built-up of macro-financial risk. Most commonly, the filtering techniques proposed by Hodrick \& Prescott (1997, HP) or Christiano \& Fitzgerald (2003, CF) are used for extraction of those deviations (e.g. Detken et al., 2014; Babecký et al., 2014; Lang, 2018). Schüler (2018) and Hamilton (2018) have recently criticized the use of the HP filter because of its tendency to induce spurious cycles. Hamilton (2018) proposes a regression of the variable on its four most recent values as a remedy. Other very common and simple alternatives are moving averages or rolling growth rates over a window of several years to capture the medium-term characteristics of the financial cycle (e.g. Schularick et al., 2016; Dell'Ariccia et al., 2016; Aikman et al., 2017; Lang et al., 2019). For reasons of simplicity, the baseline model in this study uses 3-year growth rates as the standard transformation for private credit, house prices, and equity prices. ${ }^{11}$ Table 3 displays the list of indicators, their baseline transformations, and their respective source.

Figure 4 displays event studies that show the mean and median development of the five indicators 26 quarters prior to and after the start of a crisis event. The grey band represents $50 \%$ of total observations that lie within the lower and upper quartile $\left(25^{\text {th }}\right.$ and $75^{\text {th }}$ percentiles) of the respective indicator across all countries and periods. All growth rates are yearly and computed in real terms. The figure confirms established facts about macroeconomic developments around banking crises. Growth in private credit to the nonfinancial sector increases steadily up until very close to the onset of the crisis. House and stock price hikes precede banking crises. Also, house prices tend to peak on average five to six quarters before the onset of the crisis which is in line with findings by Schudel (2015). Stock prices, on the other hand, reach their height up to ten quarters prior to the beginning of a crisis.

\footnotetext{
${ }^{11}$ For robustness, I also employ one-sided HP filters and the Hamilton (2018) procedure to extract the medium-term component of these series. The general results, however, do not change substantially.
} 
Figure 4: Behavior of indicator variables around crisis observations

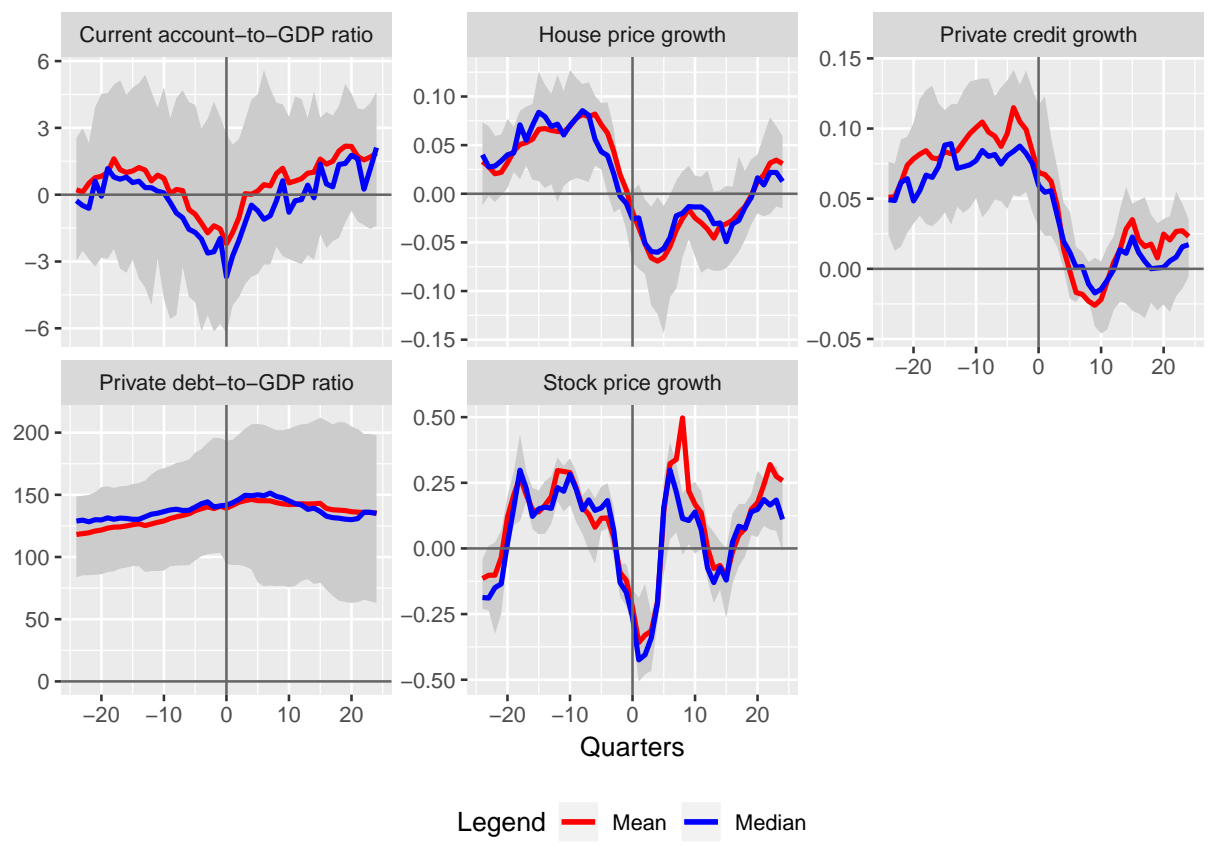

Note: This figure presents event studies of indicator variables 25 quarters before and after the beginning of a banking crisis event. Shaded areas indicate range between lower and upper quartile.

There is some indication that a worsening of the current account balance precedes crises which I examine further in the following section.

\section{THE EXPOSURE-BASED MODEL}

Building on the baseline domestic model applied to foreign countries (FCs), the exposurebased model captures the foreign-induced risk of banking crisis in a banking system abroad. The following approach is influenced by the recent pioneering work of Lang (2018) but differs in the way the foreign-induced risk is aggregated and ultimately combined with the domestic model. I define the exposure-based model as

$$
\operatorname{logit}\left(\pi^{e}\right)=\beta_{0}+\beta_{1} \frac{1}{C_{i}} \sum_{j}^{C_{i}} \hat{\pi}_{j}^{d} \underbrace{\frac{\text { bank claims }_{i}^{j}}{\mathrm{GDP}_{i}}}_{w_{i}^{j}}+\epsilon .
$$


The exposure of a home country (HC) $i$ is measured by the total outstanding bank claims ${ }_{i}^{j}$ of its banking system against foreign countries divided by the HC's GDP, as described in section two. These cross-border exposure weights $w_{i}^{j}$ are then multiplied by the respective domestic model probability $\hat{\pi}_{j}^{d}$ of those foreign economies $C_{i}$ that are connected with the HC $i$. These exposure-weighted crisis risk estimations are finally summed up for each HC and divided by $C_{i}$. The resulting number represents a weighted risk index of foreign-induced banking crises. This index is then plugged into a simple logistic regression model with a constant term to ensure an output between 0 and 1.

The Locational Banking Statistics (LBS) contain data on outstanding assets and liabilities of banks located in 47 reporting countries vis-à-vis banks located in over 200 counterparty countries. The LBS capture around $95 \%$ of cross-border banking activity worldwide. ${ }^{12}$ To fully assess an HC's risk stemming from financial linkages to banks in other countries, I consider the total number of the HC's bank claims (asset side) against these foreign countries. The underlying assumption, as described by Lang (2018) and outlined in the previous section, is that an $\mathrm{HC}$ may find itself in a state of financial instability regardless of its own domestic risk if it has lent heavily - i.e. holds foreign assets - in relation to the size of its economy to banks in foreign countries experiencing a banking crisis, making them prone to fall short of their debt obligations. ${ }^{13}$ Unfortunately not all countries report their cross-border bank claims (assets) directly to the BIS. Thus, I have to rely on the reporting countries' liability side for these economies. If data coverage was complete and data quality was perfect, a reporting country's liability vis-à-vis a country of interest should equal that country's claims (assets) vis-à-vis the same reporting country. Naturally, this is currently not the case. However, the patterns within the liability time series are consistent and, for the purpose of this paper, reporting countries' liabilities towards HCs must suffice as proxies for

\footnotetext{
12 https://www.bis.org/statistics/about_banking_stats.htm, accessed in January 2020.

${ }^{13}$ It is important to note here that, unlike the currency crisis or sudden stop literature, I am not interested in the inflow of capital into - or the lending to - the HC. These two processes represent another type of transmission channel of financial instability, especially if the flows are suddenly reversed. Here, the focus is on capturing foreign-induced banking crises and thus the HCs are modeled as lenders instead of borrowers of international funds.
} 
cross-border financial linkages where asset-side data is not available. As we will see further on, these approximations already yield highly informative results.

Figure 5: Illustration of the exposure-based model

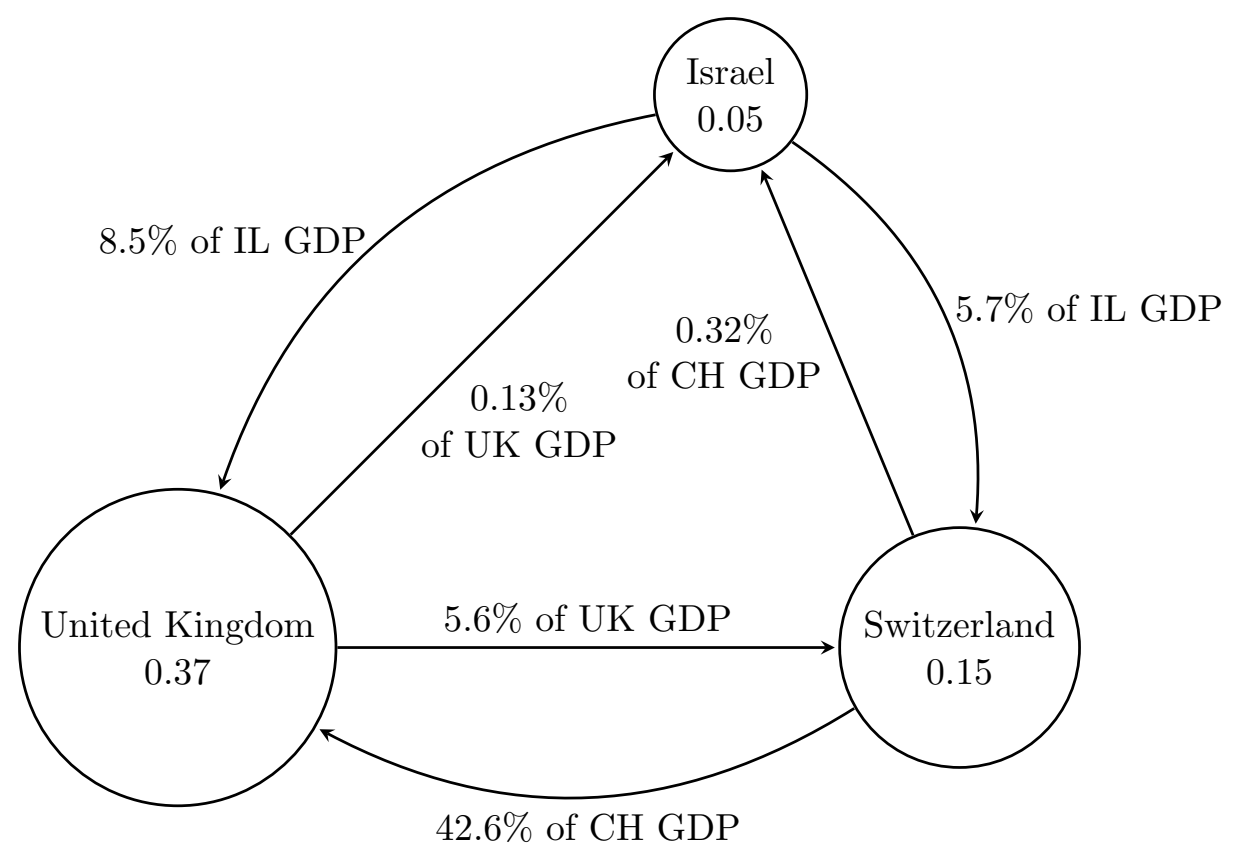

Note: The figure displays an excerpt of the cross-border network of bank claims. The number inside the circles are predicted domestic crisis probabilities and the arrows represent the volume of cross-border bank claims (pointing towards the debtor) in relation to the lending country's GDP.

The model's general idea is illustrated in Figure 5. The graph depicts a small segment of the network of cross-border bank claims that involves the two smaller countries Israel and Switzerland, and the large United Kingdom at the end of the first quarter of 2007. The numbers inside the nodes correspond to the predicted crisis probability of the country's respective domestic model out-of-sample on the basis of training data up until the end of 2006. ${ }^{14}$ The labels adjacent to the edges indicate the amount of outstanding bank claims in relation to GDP from the point of view of the lending country. The arrows point from the lender to the borrower. It is immediately visible that Israel exhibits only a marginal

\footnotetext{
14 The depicted model is estimated separately for small and large economies. I discuss the results of the estimation and evaluation process in the following section.
} 
probability of a domestically-induced banking crisis, Switzerland faces elevated risk, and the United Kingdom is confronted with a 37\% probability of imminent banking crisis over the next 3 to 12 quarters. Unlike Israel, Switzerland has large exposure to the banking system of the United Kingdom of almost $43 \%$ of its GDP and thus faces a much larger threat of foreigninduced financial instability. Switzerland's aggregated index of foreign-induced crisis risk for the entire network will likely be much higher than Israel's, and consequently the exposurebased model would predict a higher probability of foreign-induced crisis for Switzerland than for Israel. Since Israel is at the time of writing not reporting to the LBS, the assets and liabilities of Israel vis-à-vis Switzerland and the United Kingdom are not present in the source data. Israel's cross-border bank claims are proxied by the total bilateral liabilities reported by Switzerland (5.7\% of Israeli GDP) and the United Kingdom (8.5\% of Israeli GDP).

While the idea of an exposure-based early warning model originates from Lang (2018), my implementation differs substantially in the way the individual weights are aggregated as well as in how the domestic and exposure-based models are merged into a combined model. Lang (2018) uses the weights to compute exposure-based independent variables that are fed simultaneously with the domestic independent variables into a combined model. I deliberately choose to issue two distinct crisis probabilities to be able to distinguish between the impact of domestic and of foreign-induced crisis risk during the Global Financial Crisis. The policy maker's loss function and threshold optimization work exactly like described above for the domestic model. 


\section{THE COMBINED MODEL}

In a third step, the weighted risk index of foreign-induced banking crisis is plugged into the domestic model. The combined model takes the form

$$
\operatorname{logit}\left(\pi^{e}\right)=\beta_{0}+\beta_{1} X+\beta_{2} \underbrace{\frac{1}{C_{i}} \sum_{j}^{C_{i}} \hat{\pi}_{j}^{d} \frac{\text { bank claims }_{i}^{j}}{\mathrm{GDP}_{i}}}_{\text {crisis risk-weighted exposure index }}+\epsilon
$$

and is estimated for small, large, emerging, developed, and all countries separately. In a slight variation, I estimate a second model for each country set that contains an interaction term between the current account balance and the foreign-induced risk index. Since the current account balance signals whether a country is a net capital importer (deficit) or exporter (surplus), it is related to the concept of cross-border bank flows which are one type of international capital flows. The inclusion of the interaction term allows for distinguishing the unconditional effect of the current account balance on financial instability from the effect that is conditional on high exposure to foreign crisis risk. The literature has found at best moderate evidence that a current account deficit, i.e. sustained foreign capital imports, is a predictor of banking crisis (Kauko, 2014), which corresponds to the conventional view that capital inflows can lead to financial instability. With the cross-border bank lending channel, however, it is the exposure to foreign assets, not foreign liabilities, that drives up the risk of banking crisis, and I would thus expect - by tendency - a current account surplus to precede banking crises in case they are induced through foreign asset exposure. The interaction term helps to test this hypothesis.

The comparison between the domestic and the combined model gives an indication on whether the inclusion of banks' cross-border asset-side exposure matters for the explanation of financial instability in addition to the well-known domestic factors. An increase in the predictive ability of the domestic model after including the foreign-induced risk index is interpreted as evidence that the cross-border bank lending channel matters for financial in- 
stability and represents a hitherto missing puzzle piece in the macroeconomic understanding of international crisis transmission.

\section{EVALUATION}

I evaluate the models' predictive abilities in-sample and out-of-sample. For the latter, I run two exercises: First, I use cross-validation, for which the sample is randomly split into equally sized parts, and where one part alternately functions as the testing data set while the rest of the data is used to train the system. The accumulated performance measures are then averaged over all runs. Second, I compute all three models recursively to corroborate the recursive exercise. This means that for every successive quarter the entire model specification is re-estimated on the basis of the observations that are available up until the respective point in time. The accumulated predicted crisis probabilities are thus out-of-sample at the point in time where the model was estimated. As a result, the optimal thresholds vary over time as the grid optimization process is reiterated with every additional quarter.

The literature knows several informative tools to evaluate a model's predictive abilities (Candelon et al., 2012; Sarlin, 2013). In this paper, I use the popular Area Under the Receiver Operator Curve (AUROC) to assess my models' performance in-sample and out-of-sample. The AUROC is closely related to the concepts of the confusion matrix and the policy maker's loss function introduced earlier. The Receiver Operator Curve (ROC) is a two-dimensional graph that plots the sensitivity against the specificity for a range of considered threshold values (in this case $n=1000$ ). Sensitivity — or alternatively the true positive rate (TPR) - is the ratio of the correctly signaled crisis events over all crisis observations; and specificity — or alternatively the true negative rate (TNR) - is the fraction of correctly identified non-crisis events in all non-crisis events. Formally,

$$
\text { Sensitivity }=T P R=\frac{T P}{T P+F N}=1-\text { type II error rate, }
$$




$$
\text { Specificity }=T N R=\frac{T N}{T N+F P}=1-\text { type I error rate. }
$$

The ROC then plots all TPR-TNR combinations for the grid of considered threshold values. Connecting these pairs results in a frontier curve that can be summarized in one measure by computing the area underneath. The policy maker's preference then takes the form of indifference curves that are tangent to the frontier which results in different optimal TPR-TNR value pairs and thus different optimal thresholds depending on the choice for the preference parameter $\phi{ }^{15}$ The AUROC assumes values between 0 and 1 , where a value of .5 corresponds to a coin toss and every value higher than .5 indicates a predictive ability of the classification system better than a random guess. The larger the AUROC, the better the predictive ability of the model.

\section{Results}

The estimation results of the domestic model presented in Table 4 hold no surprises and are well in line with the literature, as expected. Private credit matters for the prediction of financial instability for all country sets-be it as a growth rate or in the form of the debt level. While credit growth seems to be the slightly more relevant indicator across all country sets, it is only the level of private debt that is relevant for large economies. Asset valuations, as represented by house and share prices, are strong predictors, as well, with the interesting observation that for smaller economies house price growth is not statistically significant. Evidence on the current account balance is mixed, which is mirrored well in the literature that finds, at best, a moderate role for a current account deficit as a predictor of banking distress (Kauko, 2014). For smaller economies, a current account surplus, i.e. sustained capital exports, is predictive of banking distress at $5 \%$ confidence, while for emerging economies a current account deficit matters, even if only at an $11.9 \%$ confidence level. The current account coefficient estimates for the remaining country sets are not significantly different from

${ }_{15}$ Detken et al. (2014) provide a very clear and intuitive explanation of the AUROC and its relation to the policy maker's loss function in section 2.2 of their paper. 
zero. I interpret the opposite sign directions as first evidence that my proposed distinction of a cross-border banking channel of crisis transmission into an asset side and a liability side meets evidence in the data. Cross-border claims of smaller nations with large banking sectors quickly become large in relation to the size of their real economy and thus change the direction of the economy's current account, turning it into surplus. Contrarily, the negative sign and the coefficients' sufficiently high statistical significance confirm the established finding from the currency crisis literature that sizable cross-border liabilities are predictive of banking crises in emerging economies.

Table 4: Domestic model estimations

\begin{tabular}{lccccc}
\hline Variable & \multicolumn{5}{c}{ Country Set } \\
\cline { 2 - 6 } & Small & Large & Emerging & Developed & All \\
\hline (const.) & $-5.508^{* * *}$ & $-4.837^{* * *}$ & $-8.114^{* * *}$ & $-3.836^{* * *}$ & $-4.640^{* * *}$ \\
& $(0.465)$ & $(0.407)$ & $(1.376)$ & $(0.303)$ & $(0.266)$ \\
Private credit, 3-year real growth rate & $3.860^{* * *}$ & 0.674 & $11.000^{* * *}$ & $1.098^{*}$ & $1.708^{* * *}$ \\
& $(0.768)$ & $(0.580)$ & $(2.107)$ & $(0.591)$ & $(0.441)$ \\
Private debt-to-GDP ratio & $0.007^{* * *}$ & $0.013^{* * *}$ & -0.005 & 0.002 & $0.007^{* * *}$ \\
& $(0.002)$ & $(0.003)$ & $(0.008)$ & $(0.002)$ & $(0.001)$ \\
House prices, 3-year real growth rate & -0.086 & $2.819^{* * *}$ & $-5.559^{* * *}$ & $2.838^{* * *}$ & $1.738^{* * *}$ \\
& $(0.897)$ & $(0.614)$ & $(1.905)$ & $(0.621)$ & $(0.485)$ \\
Share prices, 3-year real growth rate & $1.772^{* * *}$ & $0.796^{* * *}$ & $1.371^{* * *}$ & $1.418^{* * *}$ & $1.160^{* * *}$ \\
& $(0.230)$ & $(0.193)$ & $(0.411)$ & $(0.174)$ & $(0.138)$ \\
Current account-to-GDP ratio & $0.048^{* *}$ & -0.032 & -0.112 & -0.005 & -0.006 \\
& $(0.023)$ & $(0.030)$ & $(0.072)$ & $(0.018)$ & $(0.016)$ \\
\hline Observations & 1,515 & 1,331 & 716 & 2,130 & 2,741 \\
Pseudo R2 & 0.695 & 0.541 & 0.902 & 0.501 & 0.610 \\
AUROC & 0.897 & 0.719 & 0.960 & 0.791 & 0.781 \\
In-sample results & & & & & \\
Threshold $(\phi=0.5)$ & & & & & 0.080 \\
Sensitivity & 0.069 & 0.170 & 0.067 & 0.074 \\
Specificity & 0.840 & 0.469 & 1.000 & 0.773 & 0.682 \\
Threshold $(\phi=0.8)$ & 0.836 & 0.951 & 0.915 & 0.745 & 0.768 \\
Sensitivity & 0.038 & 0.012 & 0.067 & 0.053 & 0.040 \\
Specificity & 0.968 & 1.000 & 1.000 & 0.878 & 0.891 \\
\hline & 0.635 & 0.067 & 0.915 & 0.550 & 0.481 \\
\hline
\end{tabular}

Notes: The table displays estimation results from a pooled logistic regression model for various country sets. *, **, *** indicate significance at the $10 \%, 5 \%$, and $1 \%$ confidence level, respectively. The Pseudo $\mathrm{R}^{2}$ is computed following McFadden (1974). Sensitivity refers to the true positive rate (TPR), specificity refers to the true negative rate (TNR). 
The optimal thresholds are computed for two different policy preference scenarios: indifferent $(\phi=0.5)$ and conservative $(\phi=0.8)$. Due to the high costs involved in missing an actual crisis event, the latter can be seen as the more plausible in an applied setting. All five model estimations exhibit at least satisfactory in-sample performance. Both McFadden's (1974) Pseudo $\mathrm{R}^{2}$ and the AUROC point to strong predictive abilities. While the proposed domestic model yields good results for large and developed economies at AUROCs of 0.719 and 0.791, respectively, it performs exceptionally well for small and emerging economies with values of 0.897 and 0.960 . The pooled estimation has good predictive power at an AUROC of 0.781 , as well. These results are robust to different growth rate horizons or to whether the medium-term component in credit and asset prices was computed via HP filter or Hamilton procedure, as is shown in the appendix. I thus interpret the better fit of the model for smaller and less developed economies such that their risk of financial instability largely stems from domestic sources. I hypothesize that for larger and more developed economies there is a greater role for the cross-border bank lending channel to induce financial instability. While I expect the domestic model's performance to improve for all country sets after the inclusion of the exposure-based risk, I assume that the increase will be most significant for larger and more developed economies, bringing AUROCs across the various country sets to higher, and more uniform levels.

In an intermediate step, I estimate the exposure-based model for the same country sets as above. Results are reported in Table 5. Using a logistic model with only the crisis riskweighted exposure index as an independent variable ensures that the prediction outcome will be standardized between 0 and 1 and that it can, in this way, be compared to the output of the domestic model. The model performs best for developed economies with an AUROC of 0.696, which is only somewhat lower than the value for its domestic counterpart. I interpret this as evidence that asset-side cross-border exposure is on equal footing with domestic imbalances when explaining financial instability for developed nations. For emerging economies, on the other hand, the crisis risk-weighted exposure index does not explain the incidence of banking 
Table 5: Exposure-based model

\begin{tabular}{lccccc}
\hline Variable & \multicolumn{5}{c}{ Country Set } \\
\cline { 2 - 6 } & Small & Large & Emerging & Developed & All \\
\hline (const.) & $-3.151^{* * *}$ & $-3.284^{* * *}$ & $-2.906^{* * *}$ & $-3.094^{* * *}$ & $-3.113^{* * *}$ \\
& $(0.101)$ & $(0.129)$ & $(0.135)$ & $(0.093)$ & $(0.076)$ \\
Crisis risk-weighted exposure index & $0.233^{* * *}$ & $0.525^{* * *}$ & 0.072 & $0.273^{* * *}$ & $0.364^{* * *}$ \\
& $(0.021)$ & $(0.058)$ & $(0.125)$ & $(0.023)$ & $(0.028)$ \\
\hline Observations & 2,648 & 1,864 & 1,487 & 3,025 & 4,512 \\
Pseudo R & 0.094 & 0.105 & 0.000 & 0.087 & 0.076 \\
AUROC & 0.643 & 0.609 & 0.358 & 0.696 & 0.628 \\
& & & & & \\
In-sample results & & & & & \\
Threshold $(\phi=0.5)$ & 0.064 & 0.064 & 0.053 & 0.067 & 0.060 \\
Sensitivty & 0.483 & 0.475 & 0.538 & 0.564 & 0.503 \\
Specificity & 0.825 & 0.820 & 0.586 & 0.791 & 0.762 \\
Threshold $(\phi=0.8)$ & 0.042 & 0.001 & 0.052 & 0.001 & 0.043 \\
Sensitivty & 1.000 & 1.000 & 1.000 & 1.000 & 1.000 \\
Specificity & 0.056 & 0.000 & 0.106 & 0.000 & 0.028 \\
\hline Notes: The table & &
\end{tabular}

Notes: The table displays estimation results from a pooled logistic regression model for various country sets. $*, * *, * * *$ indicate significance at the $10 \%, 5 \%$, and $1 \%$ confidence level, respectively. The Pseudo $\mathrm{R}^{2}$ is computed following McFadden (1974). Sensitivity refers to the true positive rate (TPR), specificity refers to the true negative rate (TNR).

crises and the AUROC consequently drops to 0.358. I conclude that the proposed asset-side transmission channel does not work for economies with less developed banking systems. As the currency crisis literature states, the international transmission of banking crises to these countries works through the liability side of banks' balance sheets, i.e. by borrowing from abroad. Country size does not affect the lending channel. The country subsets for small and large economies as well as the pooled set all exhibit similar moderate performances with AUROCs above the critical threshold of 0.5 , but with significant coefficient estimates with positive signs for the exposure index, as expected.

Lastly, I investigate how well the combination of both sources of risk explains the incidence of banking crises. The estimation results of the combined model are displayed in Table 6. As expected, the overall in-sample performance improves in comparison to the domestic model and a more uniform pattern of AUROC values emerges across all country sets. The cross-border bank lending channel represents an external source of risk of financial 


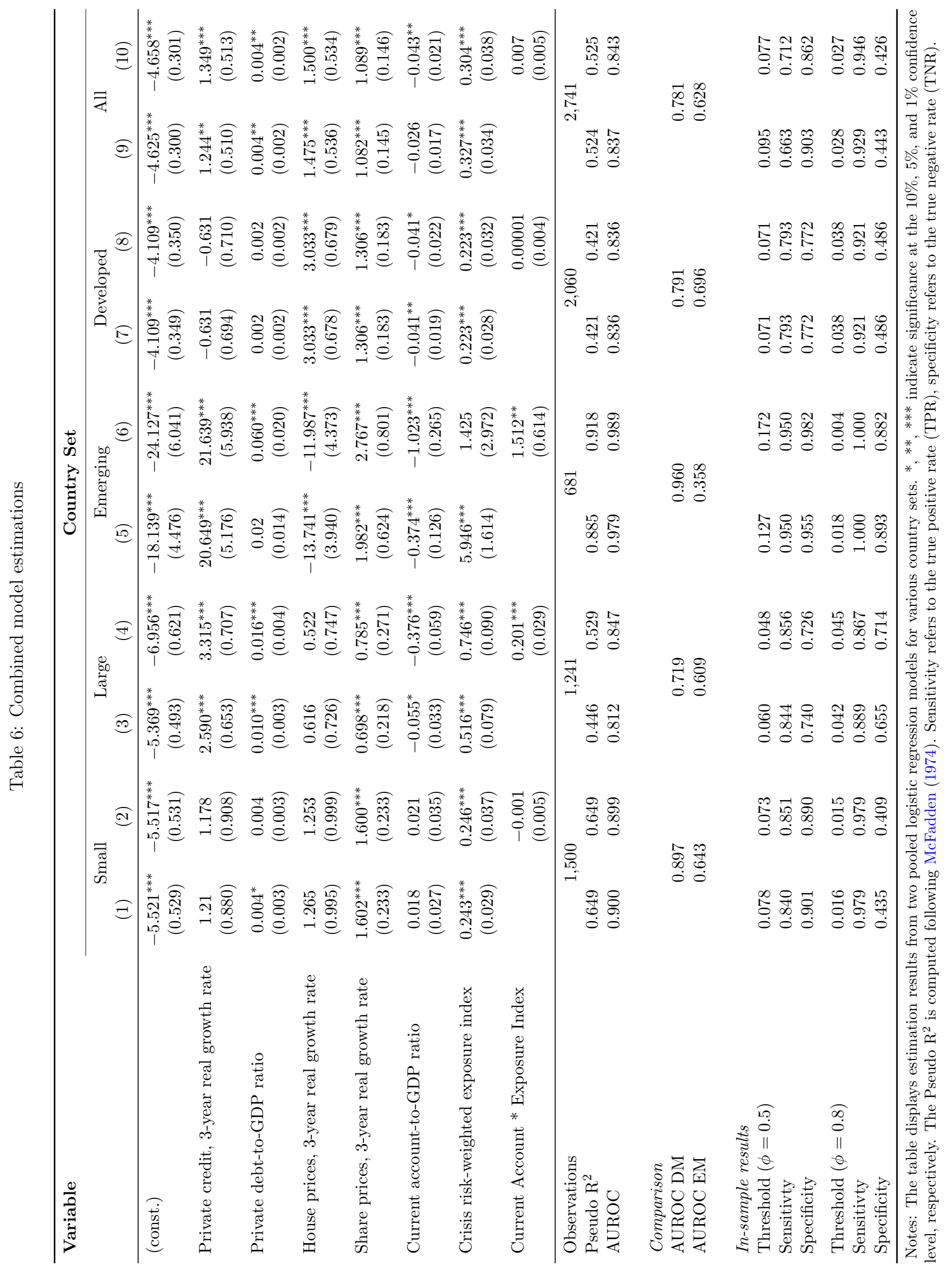


instability and its inclusion improves the general prediction of banking crisis. How substantial this improvement is, however, depends greatly on the level of development of the home banking system and to a lesser extend on the size of the home economy. ${ }^{16}$ The inclusion of the Crisis risk-weighted exposure index into the domestic model has the greatest effect for large economies with the AUROC improving by 0.09 (no interaction) and 0.13 (with interaction) to 0.812 and 0.847 , respectively. The combined model also improves domestic model estimations reasonably well for developed economies (by 0.05 each) and the pooled country set (by 0.06 each). This is in line with my previous findings that exposure-based risk from the asset-side of banks' balance sheets is increasingly predictive of financial instability the higher the country's banking system is developed. The pooled set shows similar predictive abilities only because it predominately consists of developed economies. Importantly, and confirming previous findings, the inclusion of the exposure index only adds marginally to the predictive ability of the domestic model for emerging economies: The cross-border channel of banking crisis transmission does not work through the asset-side for emerging economies. ${ }^{17}$ For small economies, the improvement is negligible, as well.

The coefficient estimates reveal several interesting patterns. ${ }^{18}$ First, there seems to be a clear distinction in how residential property prices affect financial instability: While a decline in real house prices predict crises in emerging economies, it is the other way around for developed nations: here, house price hikes are related to banking crises. I conclude that while the Minskyan asset boom-bust story applies well to developed nations, we must consider less developed economies in a different light. I conjecture that it is rather episodes

${ }^{16}$ In the appendix, I conduct a robustness test in which I estimate the exposure-based model interacting the exposure index with the private credit-to-GDP ratio - as a proxy for financial development (King \& Levine, 1993; Ang, 2008). As Table A.10 shows, the exposure-index is increasingly predictive of banking crises the higher a country is financially developed, confirming the above findings.

17 To corroborate this finding, I compute marginal effects for the combined model in the appendix to assess the magnitude of the effect from including the exposure index into the domestic model. As Figure A.9 shows, its inclusion adds positively to the probability of banking crisis in all country sets except for emerging economies, where the effect is absent and not statistically different from zero.

18 The standard errors of the coefficient estimates presented in the Table 6 do not account for within-country correlation in the error term. Clustering the error terms on the country level, however, has no effect on the interpretation of the results. This holds especially for the (non-)significance of the crisis-risk weighted exposure index. 
of deflation and capital retrenchment resulting in collapsing house prices that precede crisis in emerging economies, than bursting house price bubbles that trigger devaluations and fire sale cycles.

Second, the significance of capital retrenchments in emerging economies is also visible from the highly significant and negative coefficient estimate for the current account balance. The exposure index does significantly increase financial instability but when I interact the index with the current account its unconditional contribution becomes insignificant. It is thus only when the current account is in surplus that the exposure index explains banking crises. When the balance is in deficit the exposure does not matter for financial instability. I explain this observation by assuming that, for emerging economies, other types of crossborder capital flows must matter more than bank flows, which are the only type of flow that are represented by the exposure index. Foreign direct investments or foreign portfolio flows may be much more indicative of incumbent financial instability.

Third, while cross-border bank flows do not seem to affect the current account significantly in emerging economies, for small economies the picture looks different: While the domestic model previously found that a current account surplus, i.e. sustained capital outflows, is indicative of financial distress, this effect disappears once I control for the exposurebased risk and its interaction with the current account. The exposure index assumes the significance that was previously (positively) attributed to the current account balance. This means that cross-border bank claims have a tendency to become so large in relation to small country's GDP that they quickly determine the direction of the current account.

Fourth, the inclusion of the interaction term only really improves the predictive ability of the domestic model for large economies, making the unconditional current account balance coefficient highly significant again with a negative sign. This is in line with the argument made previously that the inclusion of the cross-border bank lending channel yields the best results for larger economies.

Fifth and last, the inclusion of the interaction term only changes results for emerging 
and large economies; all other country set estimations are virtually unaffected-be it with regard to the models' predictive ability or to the coefficient and standard error estimates. For both types of economies the current account balance remains a separate indicator of financial instability after controlling for the risk originating from cross-border bank claims. I already concluded that the negative sign and the high significance of the current account estimate most likely points towards the importance of the cross-border bank borrowing channel. For large economies, the explanation is not immediately clear: Considering that the inclusion of the interaction term makes the current account estimate significant (with a negative sign) and keeps the unconditional exposure index estimate significant, I conclude that the cross-border lending channel works regardless of the direction of the current account but is exacerbated by sustained capital imports. The message here is, that even though a large country is an overall net capital importer, sizable cross-border bank claims (which are capital exports) are still a powerful mechanism to import banking crises from abroad, even if the bank claims are small in comparison to other types of capital flows that are headed in the opposite direction.

The findings discussed above shed new light on why the current account balance so far has been difficult to employ as an early-warning indicator of banking crises. Both directions of the balance matter for financial instability: While emerging economies are more susceptible to crisis spillovers when they run a sustained deficit, i.e. capital imports, developed countries seem to have a tendency to expose themselves to foreign risk by sustained surpluses, i.e. capital exports. Bank flows - as one form of cross-border capital flows - matter most for smaller economies but can play a significant role in larger economies, too.

For the combined model, the indifferent policy scenario yields satisfactory detection rates, i.e. sensitivity and specificity scores. The potentially preferable, conservative scenario generally suffers, however, from pronounced decreases in specificity in relation to little gain in terms of sensitivity. While results look promising for emerging economies and fair for large economies the specificity drops below $50 \%$ for the other country sets. This means that in the conservative scenario the majority of issued warning signals would be false positives in 
return for sensitivity scores of around or above 0.90, which still means that every tenth crisis will be missed. Figure A.8 in the appendix displays the policy maker's trade-off between type I and type II errors against the preference parameter $\phi$ for the pooled combined model. It is visible that the type I error rate, i.e. issuing false positives, climbs up rapidly from a $\phi$ value greater than 0.7 in return for only small improvements to the type II error rate. Without imposing on the policy maker's risk aversion and considering the importance of avoiding false negatives, i.e. missing crises, it seems that a $\phi$ in the upper range of 0.5 to 0.75 is desirable for the pooled model.

\section{OUT-OF-SAMPLE PERFORMANCE}

A popular form of criticism towards recently developed crisis prediction models is that the Global Financial Crisis is responsible for the bulk of crisis observations in most samples, and that excluding this event would result in a severe loss of general validity. In this section, I present results of two out-of-sample evaluation exercises that underline the usefulness of the models I propose not only as a backward-looking explanation of crisis incidence but also as a forward-looking early-warning model of banking crises. First, I conduct cross-validation over the pooled sample and, second, I employ a recursive assessment of all three models in which the three models are continuously re-estimated for every subsequent observation in time.

Cross-validation is a systematic assessment technique of a model's out-of-sample performance. The pooled sample is randomly split into $k=5$ parts of equal size (same number of observations), called folds. ${ }^{19} k-1$ folds comprise the training data, while the randomly selected $k$ 'th fold serves as the testing data, and is, thus, not used for the model's estimation but for its validation. All $k$ possible combinations of training and testing datasets are

\footnotetext{
${ }^{19}$ I choose $k=5$ because it is in the range of commonly used number of folds and is large enough to ensure the presence of sufficient crisis observations in the training set for the model to be estimated properly. I experiment with other values for $k$ but they do not change the generally positive outcome of the validation process.
} 
then individually estimated and evaluated. Due to the randomization, the resulting AUROC measures become themselves stochastic. The cross-validation is then repeated $n=10$ times to give a more arithmetically averaged picture of the out-of-sample predictive ability of this study's dataset.

Table 7 shows the results of the cross-validation exercise. Most importantly, the AUROC estimators are all greater than 0.5 at statistical significance. Thus, they have general predictive power out-of-sample. The exposure-based model performs out-of-sample worse than its in-sample counterpart, which is not surprising. Encouragingly, the domestic model's cross-validated AUROC is not different than its in-sample estimate at $99.8 \%$ confidence. The cross-validated combined model is statistically different from its in-sample counterpart only at $83.6 \%$ confidence. Also its estimate of 0.835 is not much lower than its in-sample counterpart. In summary, the combined model does not fare much worse - and at $16.4 \%$ confidence even equally as good-out-of-sample as it does in-sample, which is an extraordinary result and evidence of its general applicability. ${ }^{20}$ Lastly, the combined out-of-sample performance is statistically greater than the domestic estimation, reconfirming the relevance of the cross-border lending channel.

The recursive exercise begins in the fourth quarter of 2004, as it is the earliest possible date for which sufficient balanced panel data is available for all country subsets and for which the estimation algorithm of the logistic regression model converges. I continuously reestimate all three models for each successive quarter up until the end of data coverage in the third quarter of 2018. By computing the model predictions subsequently with information that is known at each respective time point alone, I prevent a look-ahead bias. Starting in 2004 means that the first recursive model estimation already factors in a number of crisis observations, for instance the Japanese crisis or the Scandinavian crises in the early 1990s. Again, I separate between small, large, developed, and emerging economies, and consider

${ }^{20}$ Cross-validating a dataset naturally destroys the relevance of the data's time dimension due to random slicing. The second out-of-sample assessment using a recursive estimation accounts, however, accounts for the chronology of observations. 
Table 7: Out-of-sample cross-validation results

\begin{tabular}{lccc}
\hline Measure & \multicolumn{3}{c}{ Model } \\
\cline { 2 - 4 } & Domestic & Exposure-based & Combined \\
\hline AUROC mean & 0.798 & 0.587 & 0.835 \\
AUROC standard deviation & 0.036 & 0.060 & 0.039 \\
Degrees of freedom & 49 & 49 & 49 \\
Pooled I-S estimation & 0.781 & 0.628 & 0.843 \\
& & & \\
T-test p-values: & 0.000 & 0.000 & 0.000 \\
H0: Different from 0.5 & 0.998 & 0.000 & 0.836 \\
H1: Different from I-S estimation & 0.002 & 1.000 & 0.164 \\
H2: Not Different from I-S estimation & & 0.000 & 0.000 \\
H3: AUROC different from DM & & & \\
\hline
\end{tabular}

Notes: Cross-validation is computed with $k=5, n=10, \phi=0.5$ on the pooled dataset without including the interaction term. Including the interaction term does not alter the results. I-S stands for in-sample. To account for non-equal variances when comparing two samples I employ Welch's (1947) t-tests.

a pooled dataset, as well. I compute sensitivity and specificity measures after running the exercise for each country subset and compare their relative performances. ${ }^{21}$

Figure 6 displays the development of the estimated crisis probabilities and thresholds over time for the combined model and for all countries with sufficient data available. It is evident that for many countries which experienced domestic banking crises the crisis probability rises above the threshold well before the beginning of the respective crisis, as indicated by the shaded areas. This is an impressive result considering that it excludes all crisis observations during the Global Financial Crisis from the training data as they were no known at the time of the prediction. Especially, the domestic crises in Belgium, Denmark, France, Great Britain, Ireland, Netherlands, Norway, Russia, Spain, Sweden, and Switzerland could have been predicted out-of-sample if the model had been in place before

${ }^{21}$ For this exercise, AUROCs cannot be used as an assessment of predictive ability. Effectively, there is no overall threshold choice anymore over which an AUROC could be computed. Each quarter has already been assigned its optimal threshold considering the data available at the time. The optimal threshold value for the entire recursive exercise is thus time-varying. However, we can compute the sensitivity and specificity based on these optimal thresholds and the respective crisis probability predictions at each quarter. 
Figure 6: Recursive out-of-sample exercise of the combined model
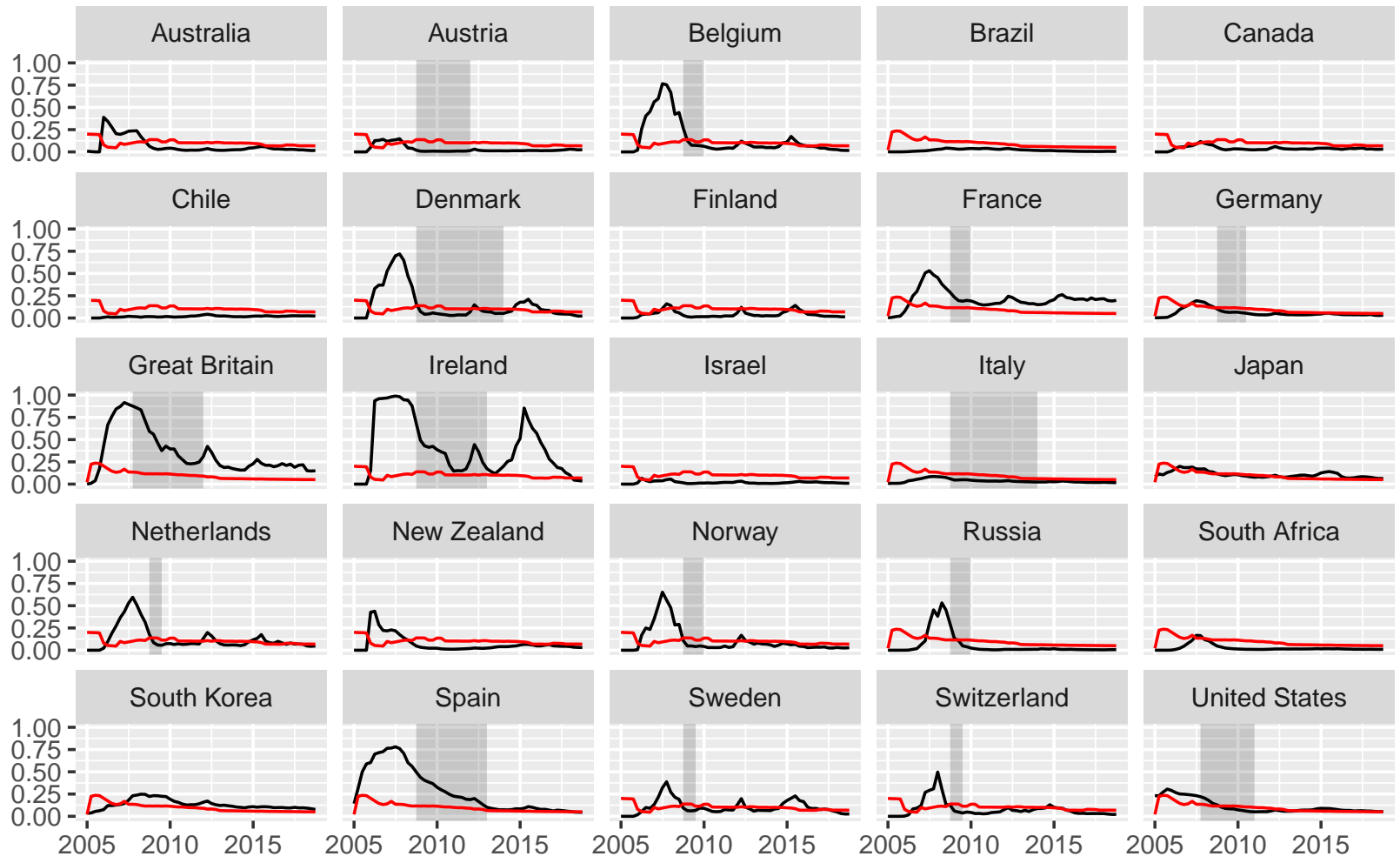

\section{Legend — Prediction — Threshold}

Note: The figure displays recursively estimated out-of-sample crisis probabilities and respective time-varying thresholds for a subset of countries with sufficient data. Shaded areas represent periods of banking crises. The combined model is estimated for small and large economies separately without using the interaction term between the crisis-risk weighted exposure index and the current account balance.

2008. It further succeeds in forecasting that Brazil, Canada, Chile, Finland, Israel, and South Africa remain resilient with their predicted probabilities not - or only briefly — breaching the threshold. Contrarily, the out-of-sample prediction of resilience would not have worked for Australia, New Zealand, and South Korea. Lastly, the picture is a little more mixed with the correct predictions that were less clearly above the thresholds as for Austria, Germany, and the United States. Here the model would have nonetheless issued warning signals, but a much clearer outcome - especially with regard to the United States as the global crisis' epicenter - would have been preferable. 
In summary, however, the out-of-sample performance gives not only credibility to the methodology in terms of its potential as an early-warning model, but it also makes a case against the argument that it is only the observations of the Global Financial Crisis that drive the good in-sample performance. Excluding this event all together would have still yielded very good prediction results and further supports my argument of the general applicability of the cross-border lending channel beyond the Global Financial Crisis.

Table 8: Out-of-sample recursive results

\begin{tabular}{lccc}
\hline Measure & \multicolumn{3}{c}{ Country Set } \\
\cline { 2 - 4 } & Small / Large & Emerg. / Dev. & All \\
\hline Domestic model & 0.731 & 0.692 & 0.692 \\
Sensitivity & 0.662 & 0.752 & 0.773 \\
Specificity & & & \\
Exposure-based model & & & 0.567 \\
Sensitivity & 0.736 & 0.607 & 0.684 \\
Specificity & 0.775 & 0.757 & \\
& & & 0.567 \\
Exposure-based model IT & & & 0.684 \\
Sensitivity & 0.736 & 0.607 & \\
Specificity & 0.775 & 0.757 & 0.273 \\
Combined model & & & 0.806 \\
Sensitivity & 0.800 & 0.731 & \\
Specificity & 0.837 & 0.838 & 0.258 \\
Combined model IT & & & 0.737 \\
Sensitivity & 0.792 & 0.746 & \\
Specificity & 0.850 & 0.792 & \\
\hline
\end{tabular}

Notes: Emerg. refers to emerging economies. Dev. refers to developed economies. IT refers to the inclusion of the interaction term between the current account balance and the crisis-risk weighted exposure index.

Table 8 summaries the results of the recursive exercise quantitatively by displaying the actual sensitivity and specificity scores over the entire time span for the individual models and country sets. One of the main findings of this paper-namely that the inclusion of exposurebased risk from cross-border bank flows increases the predictive ability of purely domestic 
early warning models - is reconfirmed: The combined model's sensitivity and specificity scores are higher than those of their domestic counterparts for the model specifications where small and large, or emerging and developed economies, respectively, are estimated separately. Interestingly, this does not hold for the pooled approach. Here, the recursive exercise lets the sensitivity collapse way below 0.5. The exclusion of the Global Financial Crisis for the estimation of the majority of crisis events in the sample underlines the importance of distinguishing between the economic characteristics of the countries in question.

Summarizing the results from both exercises, a clear picture emerges: The model arguably has predictive power out-of-sample and qualifies for application in a policy setting. Although the majority of crisis observations in the sample occur during the Global Financial Crisis, the proposed combined model still produces very satisfactory prediction results with sensitivity and specificity scores around or above 0.8 if trained recursively. Similarly, the exposure-based model exhibits scores (well) above 0.6, indicating predictive power. This supports the notion that it is not just the recent major crisis event that enables the cross border lending channel in the model, but that it is a general phenomenon that was at work before.

\section{The Global Financial Crisis}

We saw that accounting for foreign-induced crisis risk originating from cross-border bank claims improves the performance of a model that considers domestic risks alone. Now, I turn back to the puzzle of crisis incidence during the Global Financial Crisis that I laid out in the introduction. Figure 7 shows the in-sample performance of the three models from a perspective of issued warning signals between the first quarter of 2006 and the first quarter of 2013. Lime green boxes stand for true positive predictions (as subsequently determined) and dark green ones for true negatives in the respective quarter. False negatives (missed crises) are assumed to be more costly than false positives (erroneous warnings) and are thus colored in red while false positives are represented in orange. The dark blue boxes indicate 
actual crisis periods while the light blue stands for the gap between the beginning of a crisis and the lower bound of the pre-crisis horizon (i.e. three quarters) where predictions are too close time-wise to the subsequent event to be useful for the policy maker. However, in none of the cases presented did it occur that a signal would only be issued one or two quarters ahead of a crisis event. Lastly, grey boxes indicate the absence of data.

We observe that the domestic model is unable to explain crisis incidence in Italy and German, while the exposure-based model fails to predict distress in Hungary and Greece. The domestic model further issues false warnings for South Africa, New Zealand, Finland, and Australia. This is an expected outcome, as all these countries experienced a significant built-up of private credit and house prices in the years preceding the Global Financial Crisis, inducing expectations of domestic imbalances and a Minskyan boom. ${ }^{22}$. However, none of these countries actually experienced a banking crisis. The key to why this may have been the case, lies in the results of the exposure-based model for these economies: With the exception of Finland, the model signals low exposure to high-risk banking systems abroad and, thus, consequently issues no warning signal, resulting in true negatives. For Finland, however, the proposed model does not work.

Now, combing domestic imbalances with exposure-based risk from cross-border lending yields a much better picture: The combined model predicts crisis incidence perfectly, if we consider, in the case of Italy, four consecutive quarters of warning signals as a sufficient indication of impending crisis. ${ }^{23}$ Also, the combined model correctly issues warning signals for Germany: The country experienced negative real house price growth and no significant builtup of private credit, but, nonetheless, a severe banking crisis developed from banks' exposure to British and American liabilities, i.e. subprime mortgages. In predicting resilience, the combined model is a little weaker as it would have falsely issued consistent warning signals

22 Source: https://stats.bis.org/statx/srs/table/h2 and https://stats.bis.org/statx/srs/ table $/ j$ ? $m=C$, accessed June 2020 .

23 The case of Italy is somewhat special: Baron \& Dieckelmann (2020) argue that contrary to the assessment of Laeven \& Valencia (2018), Italy's banking crisis did not start until 2010, as its banking system was initially not heavily impacted through its exposure to foreign liabilities in high-risk countries, but later because of its massive holdings of sovereign bonds of southern European countries threatened by default. 
Figure 7: Warning signals around the Global Financial Crisis

\section{Domestic}

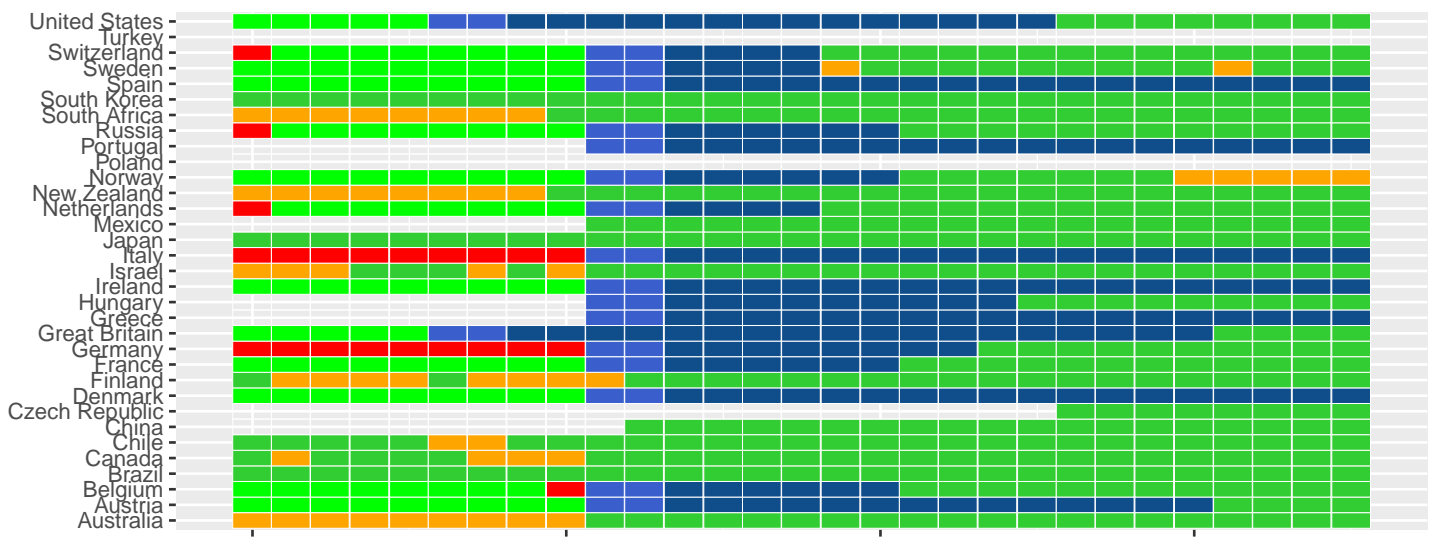

\section{Exposure-based}

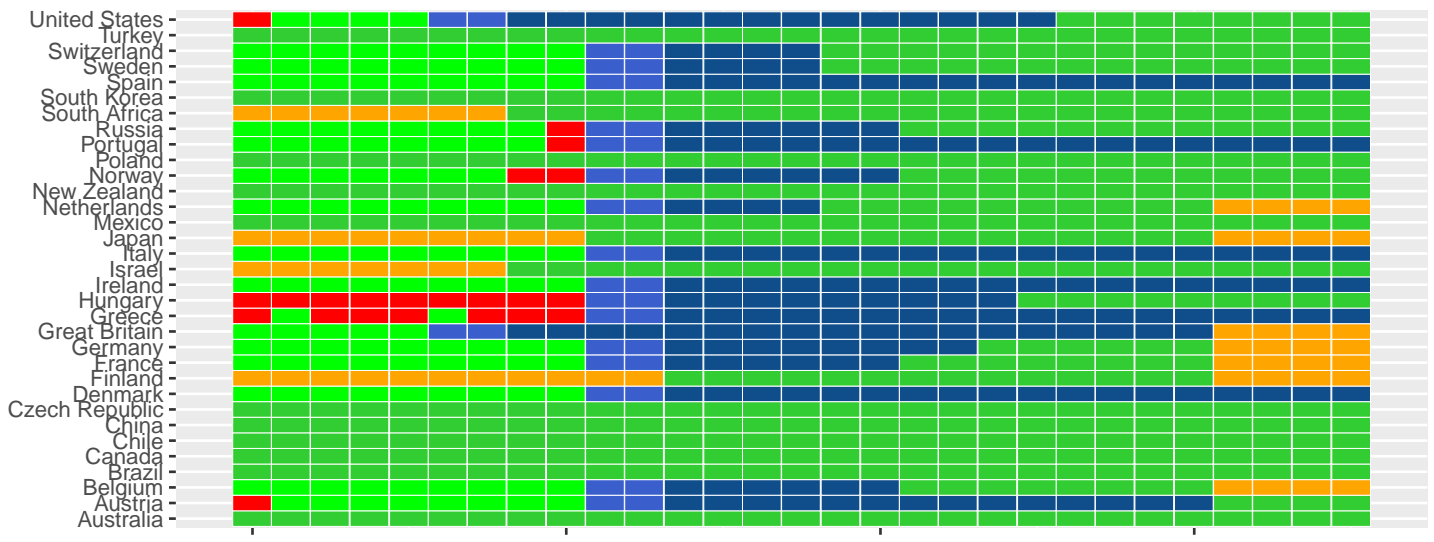

\section{Combined}

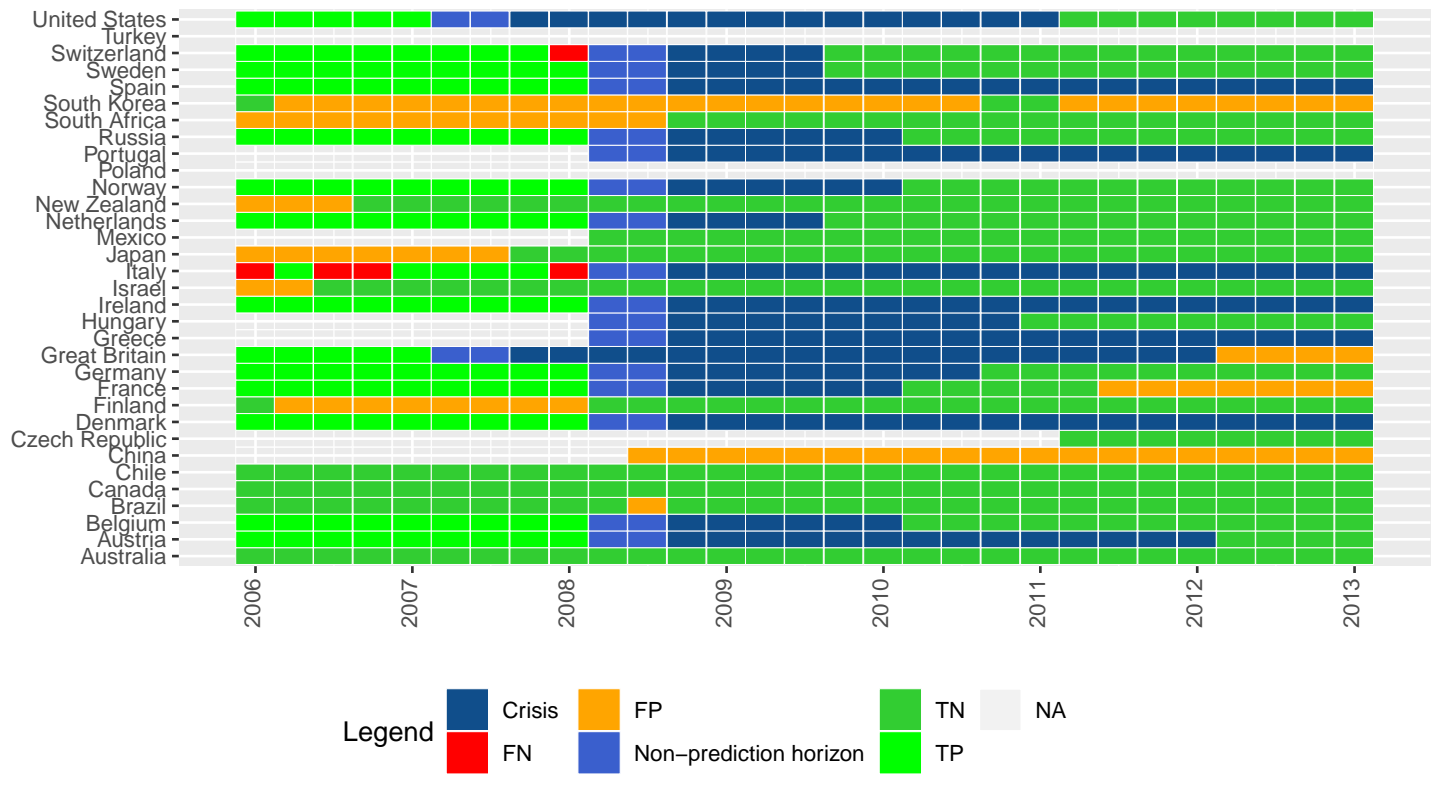


for South Korea, South Africa, Japan, and Finland. The important take away is, however, that even though the incidence of resilience may not have been conclusively addressed, the incidence of banking crisis can be explained by the combination of the domestic and the exposure-based channel.

In summary, large exposure to highly leveraged foreign banking systems is the missing puzzle piece in the Minskyan narrative of the Global Financial Crisis. The combination of the two sources of financial instability together explain crisis incidence perfectly within the sample of this study. Conversely, low asset-side exposure on the balance sheets of domestic banks seem to have been a major factor in explaining the resilience of many, often highlyleveraged economies, outside of Europe and the United States.

\section{Conclusion}

This paper contributed to the literature threefold. First, it introduces and provides evidence for a new channel of international banking crisis transmission working through banks' cross-border asset-side exposure. Sizable cross-border bank claims on foreign countries with high probability of domestic systemic risk function as a channel of contagion to the home economy. The cross-border bank lending channel stands in contrast to traditional views that see banking crises either as a result of domestic boom-bust dynamics or of cross-border borrowing in foreign currency. Second, I present a significantly improved early-warning technique to capture both domestic and foreign-induced risk of banking crisis, that incorporates the exposure to at-risk foreign banking systems in a network setting. The presented model outperforms traditional approaches that consider purely domestic risks considerably, both in and out-of-sample. Third, this study provides evidence that the proposed channel is dependent on the level of financial development. While it is active and highly predictive of banking crisss in developed countries, no evidence can be found for its effectiveness in emerging economies. Here, the classical cross-border borrowing narrative applies. The inclusion of the international bank lending channel in an early warning setting, as also recently proposed 
by Aldasoro et al. (2018) and Lang (2018), stands in contrast to the established notion of international borrowing as an external source of financial instability that is well known from the currency crisis and external debt crisis literatures (Frankel \& Rose, 1996; Reinhart et al., 1998; Reinhart \& Rogoff, 2009)

The early-warning system in this study combines into a single system a domestic modelwhich uses standard multivariate logistic regressions with a binary banking crisis classifier as dependent variable and a set of macro-financial indicators as independent variables — with an exposure-based model — which employs a weighted sum of domestic crisis probabilities in foreign countries on which the home economy has bank claims. As weights, I use the volume of the home country's cross-border asset-side exposure in relation to the size of its economy. The model is set up in such a way that it issues warning signals in a pre-crisis period of 3 to 12 quarters before a predicted banking crisis to allow for the policy maker to apply counter measures.

As mentioned in the introduction, the incidence of banking crises in countries around the globe poses a puzzle to macro-finance and the banking crisis literature. The prevalent narratives of Minskyan boom-bust cycles or contagion through borrowing can not explain why highly leveraged economies like Australia and New Zealand were not affected, while low-risk economies like Germany and Switzerland were. A first of four major findings solves this puzzle: Including domestic banks' asset-side exposure to foreign banking systems in high-risk countries into a model of domestic imbalances explains crisis incidence. During the Global Financial Crisis economies with low cross-border exposure proved resilient towards the incidence of systemic banking crises. Although these countries may have exhibited domestic imbalances, like in the case of Australia, the low exposure shielded them from spill-overs from the United States, the United Kingdom, and other adversely affected economies. Conversely, economies without large domestic imbalances, like Switzerland or Germany, still suffered from banking crises as their international exposure made them vulnerable to the imbalances within foreign banking systems. Overall, small open economies with low exposure to high- 
risk economies, such as Australia, Canada, Israel, Finland, and New Zealand, were spared from the effects of the Global Financial Crisis through the cross-border banking channel. ${ }^{24}$

A second major finding of this study is that the relevance of the lending channel increases with financial development. The channel is relevant only for developed banking systems, while the borrowing channel remains relevant for less developed banking systems. I reckon that this may have to do with insufficient domestic saving levels in emerging economies that result in funds being allocated through banks at home rather than abroad. Various forms of financial repression or a higher rate of return from domestic lending than from foreign lending may also play a role.

In a third finding, the paper addresses why the current account has hitherto been such a unreliable predictor of banking crisis. While the currency crisis literature finds that current account deficits precede financial crises, the evidence for general banking crises is mixed at best (Frankel \& Saravelos, 2012; Kauko, 2014). The results in this study show that for emerging economies, a current account deficit is predictive of banking crises, while for smaller developed economies a surplus tends to be predictive. This disparity seems convincing if one considers that the typical victims of currency crises are emerging economies.

Fourth and last, the functioning of the cross-border lending channel is independent of the current account balance, except for emerging economies. For developed economies, outward bank flows are predictive of financial instability regardless of the direction of net capital flows. For emerging economies, the situation is reversed. I conclude that looking at net flows alone is not sufficient to grasp the full picture of potential external sources of instability. Bank lending can induce financial instability in financially developed economies irrespective of the size and direction of other types of financial flows. ${ }^{25}$

I recognize several avenues for future research. Using the asset-side of the Locational Banking Statistics for all countries in the sample would enhance the accuracy of the cross-

\footnotetext{
${ }^{24}$ Naturally, these economies were still affected in the aftermath by the global collapse in confidence, trade and resource prices.

${ }^{25}$ Which is not to say that these flows may pose their own dangers to financial instability. Their assessment, however, is beyond the scope of this paper.
} 
border exposure measures. For this, more nations would have to start reporting their data to the BIS. Also, prolonging quarterly data on house prices and on the current account and for several countries with limited coverage would give a more complete picture of the factors that made the difference in crisis incidence during the recent crisis. Adding more emerging economies to the sample would bring down the standard errors in the regression coefficient estimates and provide a more complete picture on the channel and its relationship with financial development. In the same vain, it may be interesting to set-up an exposure-based model from the liability side to test the workings of the cross-border borrowing channel. Last, investigating in how far the cross-border bank lending channel has been active historically would add greatly to its consideration in the literature but may be challenging because of the current lack of historical cross-border bank data.

The findings of this paper are particularly valuable for policy makers in developed economies. Macroprudential units should monitor the built-up of domestic imbalances in foreign countries that their own country has financial ties with. Large amounts of outstanding cross-border bank claims in relation to the home country's GDP against foreign countries with elevated risk of banking crises can become disastrous even regardless of the conditions at home. The early warning system proposed in this paper constitutes a significant improvement over conventional early warning systems that focus solely on the domestic channel of banking crises, and represents a valuable contribution that will greatly enhance policy makers' capabilities and that will help preventing financial catastrophes in the future. 


\section{REFERENCES}

Aikman, D., Haldane, A. G., \& Nelson, B. D. (2015). Curbing the credit cycle. Economic Journal, 125(585), 1072-1109.

Aikman, D., Kiley, M., Lee, S. J., Palumbo, M. G., \& Warusawitharana, M. (2017). Mapping heat in the U.S. financial system. Journal of Banking and Finance, 81, 36-64.

Aldasoro, I., Borio, C., \& Drehmann, M. (2018). Early warning indicators of banking crises: expanding the family. BIS Quarterly Review, March, 29-45.

Alessi, L. \& Detken, C. (2011). Quasi real time early warning indicators for costly asset price boom/bust cycles: A role for global liquidity. European Journal of Political Economy, 27(3), 520-533.

Ang, J. B. (2008). A survey of recent developments in the literature of finance and growth. Journal of Economic Surveys, 22(3), 536-576.

Babecký, J., Havránek, T., Matějů, J., Rusnák, M., Šmídková, K., \& Vašíček, B. (2014). Banking, debt, and currency crises in developed countries: Stylized facts and early warning indicators. Journal of Financial Stability, 15, 1-17.

Baron, M. \& Dieckelmann, D. (2020). The Historical Banking Crisis Database, 1870-2016. Unpublished manuscript.

Baron, M., Verner, E., \& Xiong, W. (2020). Banking crises without panics. NBER Working Paper, 26908.

Berkmen, S. P., Gelos, G., Rennhack, R., \& Walsh, J. P. (2012). The global financial crisis: Explaining cross-country differences in the output impact. Journal of International Money and Finance, 31(1), 42-59.

Bordo, M. D., Eichengreen, B., Klingebiel, D., Martinez-Peria, M. S., \& Rose, A. K. (2001). Is the crisis problem growing more severe? Economic Policy, 16(32), 53-82.

Borio, C. \& Lowe, P. (2002). Asset prices, financial and monetary stability: exploring the nexus. BIS Working Paper, 114.

Brunnermeier, M. K. \& Sannikov, Y. (2014). A macroeconomic model with a financial sector. American Economic Review, 104 (2), 379-421.

Bruno, V. \& Shin, H. S. (2015). Cross-border banking and global liquidity. Review of Economic Studies, 82(2), 535-564.

Bussiere, M. \& Fratzscher, M. (2006). Towards a new early warning system of financial crises. Journal of International Money and Finance, 25 (6), 953-973.

Candelon, B., Dumitrescu, E.-I., \& Hurlin, C. (2012). How to evaluate an early-warning system: toward a unified statistical framework for assessing financial crises forecasting methods. IMF Economic Review, 60(1), 75-113. 
Christiano, L. J. \& Fitzgerald, T. J. (2003). The band pass filter. International Economic Review, 44(2), 435-465.

Claessens, S. \& Kose, M. A. (2013). Financial Crises: Explanations, Types and Implications.

Dell'Ariccia, G., Igan, D., Laeven, L., \& Tong, H. (2016). Credit booms and macrofinancial stability. Economic Policy, 31 (86), 299-355.

Demirgüç-Kunt, A. \& Detragiache, E. (1998). The determinants of banking crises: evidence from developing and developed countries. Staff Papers - International Monetary Fund, 45(1), 81-109.

Detken, C., Weeken, O., Alessi, L., Bonfim, D., Boucinha, M. M., Castro, C., Frontczak, S., Giordana, G., Giese, J., Jahn, N., Kakes, J., Klaus, B., Lang, J. H., Puzanova, N., \& Welz, P. (2014). Operationalising the countercyclical capital buffer: indicator selection, threshold identification and calibration options. ESRB Occasional Paper, 5.

Drehmann, M., Borio, C., \& Tsatsaronis, K. (2012). Characterising the financial cycle: Don't lose sight of the medium term! BIS Working Paper, 380.

Eggertsson, G. B. \& Krugman, P. (2012). Debt, Deleveraging and the Liquidity Trap: a Fischer-Minsky-Koo Approach. Quarterly Journal of Economics, 127(3), 1469-1513.

Fisher, I. (1933). The Debt-Deflation Theory of Great Depressions. Econometrica, 1(4), 337.

Frankel, J. A. \& Rose, A. K. (1996). Currency crashes in emerging markets: An empirical treatment. Journal of International Economics, 41, 351-366.

Frankel, J. A. \& Saravelos, G. (2012). Can leading indicators assess country vulnerability? Evidence from the 2008-09 global financial crisis. Journal of International Economics, $87(2), 216-231$.

Hamilton, J. D. (2018). Why you should never use the Hodrick-Prescott filter. The Review of Economics and Statistics, 100(5), 831-843.

Hodrick, R. J. \& Prescott, E. C. (1997). Postwar U.S. business cycles: an empirical investigation. Journal of Money, Credit and Banking, 29(1), 1-16.

Holopainen, M. \& Sarlin, P. (2017). Toward robust early-warning models: a horse race, ensembles and model uncertainty. Quantitative Finance, 17(12), 1933-1963.

Jordà, Ò., Schularick, M., \& Taylor, A. M. (2017). Macrofinancial history and the new business cycle facts. In M. Eichenbaum \& J. A. Parker (Eds.), NBER Macroeconomics Annual 2016, volume 31 (pp. 213-263). Chicago, IL: University of Chicago Press.

Kaminsky, G. L. \& Reinhart, C. M. (1999). The twin crises: The cause of banking and balance of payment problems. American Economic Review, 89(3), 473-500. 
Kaminsky, G. L. \& Reinhart, C. M. (2000). On crises, contagion, and confusion. Journal of International Economics, 51(1), 145-168.

Karolyi, G. A., Sedunov, J., \& Taboada, A. G. (2018). Cross-border bank flows and systemic risk. SSRN Electronic Journal.

Kauko, K. (2014). How to foresee banking crises? A survey of the empirical literature. Economic Systems, 38(3), 289-308.

Kindleberger, C. P. \& Aliber, R. Z. (2015). Manias, panics and crashes: a history of financial crises (7th ed.). Palgrave Macmillan.

King, R. G. \& Levine, R. (1993). Finance and Growth: Schumpeter Might Be Right. The Quarterly Journal of Economics, 108(3), 717-737.

Laeven, L. \& Valencia, F. (2018). Systemic Banking Crises Revisited. IMF Working Papers, $18 / 206$.

Lane, P. R. \& Milesi-Ferretti, G. M. (2011). The cross-country incidence of the global crisis. IMF Economic Review, 59(1), 77-110.

Lang, J. H. (2018). Cross-country linkages and spill-overs in early warning models for financial crises. ECB Working Paper, 2160.

Lang, J. H., Izzo, C., Fahr, S., \& Ruzicka, J. (2019). Anticipating the bust: a new cyclical systemic risk indicator. ECB Occasional Paper, 219.

Lo Duca, M., Koban, A., Basten, M., Bengtsson, E., Klaus, B., Kusmierczyk, P., Lang, J. H., Detken, C., \& Peltonen, T. (2017). A new database for financial crises in European countries: ECB / ESRB EU crises database. ECB Occasional Paper, 194.

McFadden, D. (1974). Conditional logit analysis of qualitative choice behaviour. In P. Zarembka (Ed.), Frontiers in Econometrics chapter 4, (pp. 105-142). New York: Academic Press.

Minoiu, C., Kang, C., Subrahmanian, V. S., \& Berea, A. (2015). Does financial connectedness predict crises? Quantitative Finance, 15(4), 607-624.

Minsky, H. P. (2008). Stabilizing an unstable economy. McGraw-Hill.

Reinhart, C. M., Kaminsky, G. L., \& Lizondo, S. (1998). Leading Indicators of Currency Crises. IMF Staff Papers, 45(1), 1-48.

Reinhart, C. M. \& Rogoff, K. S. (2009). This time is different: eight centuries of financial folly. Princeton University Press.

Romer, C. D. \& Romer, D. H. (2017). New evidence on the impact of financial crisis in advanced countries. American Economic Review, 107(10), 3072-3118.

Rose, A. K. \& Spiegel, M. M. (2010). Cross-country causes and consequences of the 2008 crisis: international linkages and american exposure. Pacific Economic Review, 15(3), 340-363. 
Rose, A. K. \& Spiegel, M. M. (2011). Cross-country causes and consequences of the crisis: An update. European Economic Review, 55(3), 309-324.

Sarlin, P. (2013). On policymakers' loss functions and the evaluation of early warning systems: Comment. Economics Letters, 119(1), 1-7.

Schnabl, P. (2012). The international transmission of bank liquidity shocks: evidence from an emerging market. Journal of Finance, 67(3), 897-932.

Schudel, C. J. W. (2015). Shifting horizons: Assessing macro trends before, during, and following systemic banking crises. ECB Working Paper, 1766.

Schularick, M. \& Taylor, A. M. (2012). Credit Booms Gone Bust: Monetary Policy, Leverage Cycles and Financial Crises, 1870-2008. American Economic Review, 102(2), 1029-1061.

Schularick, M., Taylor, A. M., \& Jordà, Ò. (2016). The great mortgaging: housing finance, crises and business cycles. Economic Policy, 31(85), 107-152.

Schüler, Y. S. (2018). Detrending and financial cycle facts across G7 countries: mind a spurious medium term! ECB Working Paper, 2138.

Strohsal, T., Proaño, C. R., \& Wolters, J. (2015). Characterizing the financial cycle: evidence from a frequency domain analysis. Deutsche Bundesbank Discussion Paper, 22.

Welch, B. L. (1947). The Generalization of 'Student's' Problem when Several Different Population Variances are Involved. Biometrika, 34 (1/2), 28-35. 


\section{APPENDIX}

Figure A.8: Policy maker's preference trade-off

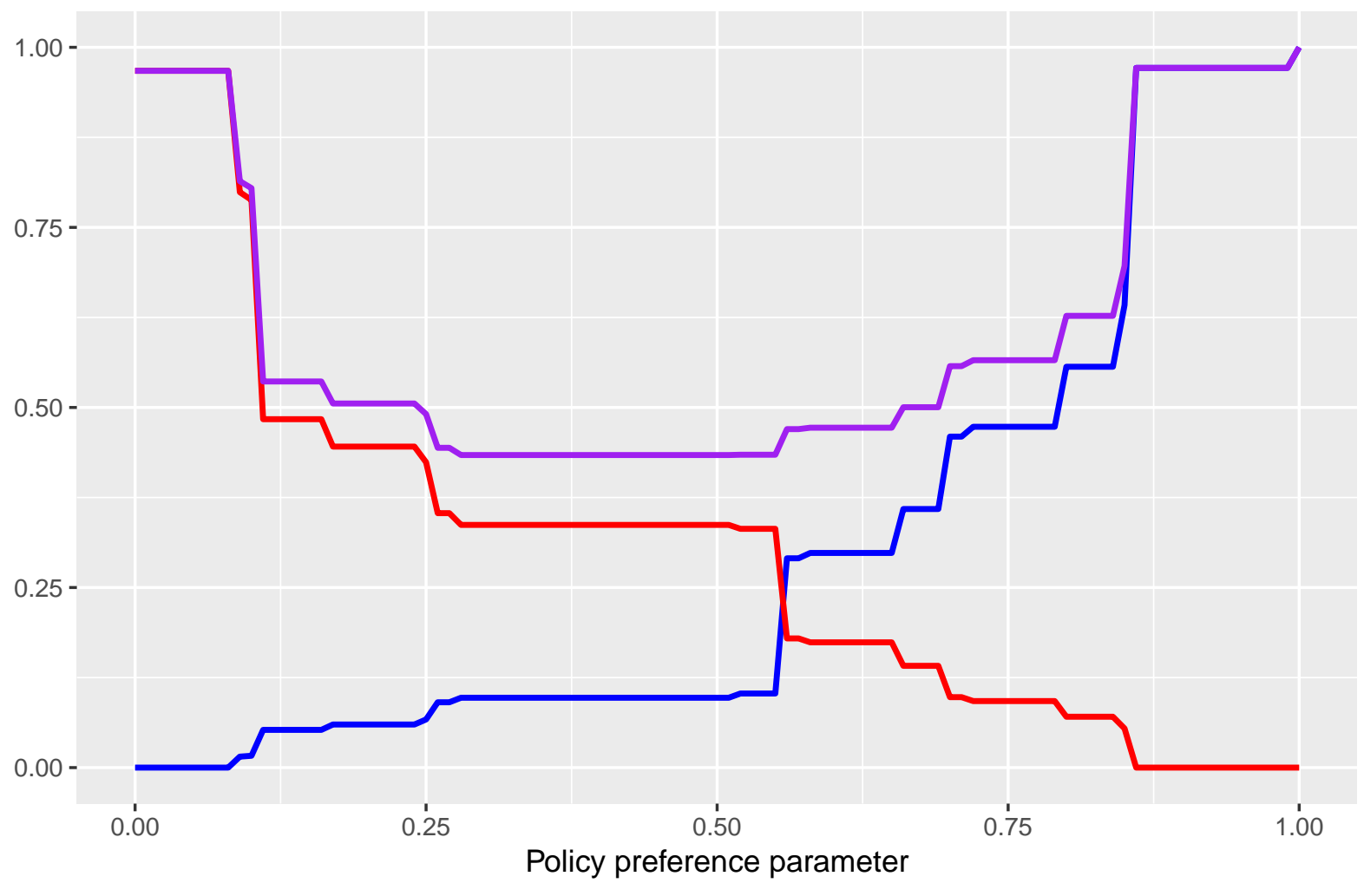

Legend - Sum — Type I error rate - Type II error rate 
Figure A.9: Marginal effects of the combined model
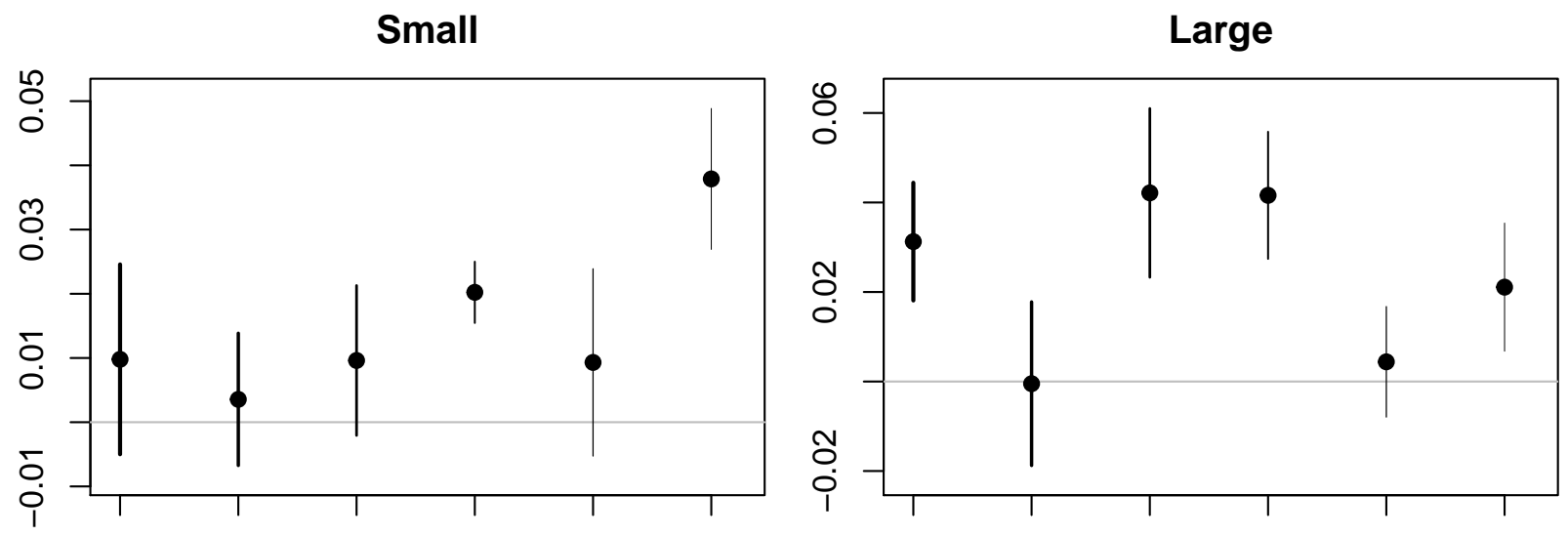

Emerging
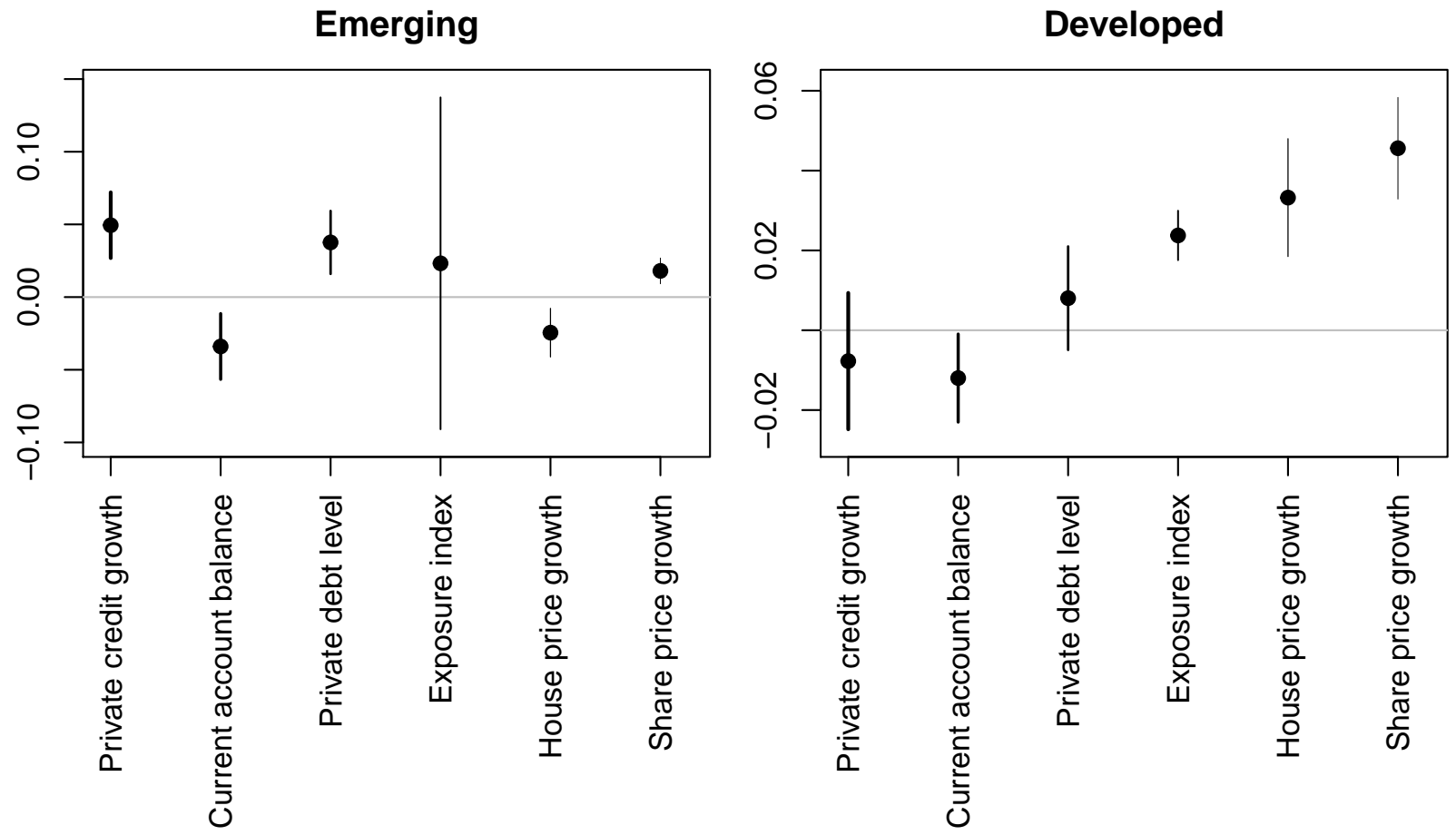

Note: Displayed above are marginal effects of the combined model, computed for the separate country sets including the interaction term between the exposure index and the current account balance. All observations of each explanatory variable are standardized to a mean of 0 and a standard deviation of 1 to ensure comparability of the marginal effects. Thus, the displayed marginal effects are the expected change in crisis probability in response to a one-standard deviation shock to the respective variable. It is visible from the plots that for all country sets except for emerging economies the exposure index adds positively and significantly to a higher probability of banking crisis. For emerging economies, the effect's standard errors are large and contain the zero, from which no positive effect on financial instability can be derived. This corroborates the study's finding that the cross-border lending channel of banking crisis transmission is not active for emerging economies. For all other country sets its contribution to probability is substantial, positive, and significantly above zero, which means that the inclusion of the exposure index is the factor that increases the AUROC in comparison to the domestic model. The slight increase of the combined model's AUROC for emerging economies is thus due to randomness. 


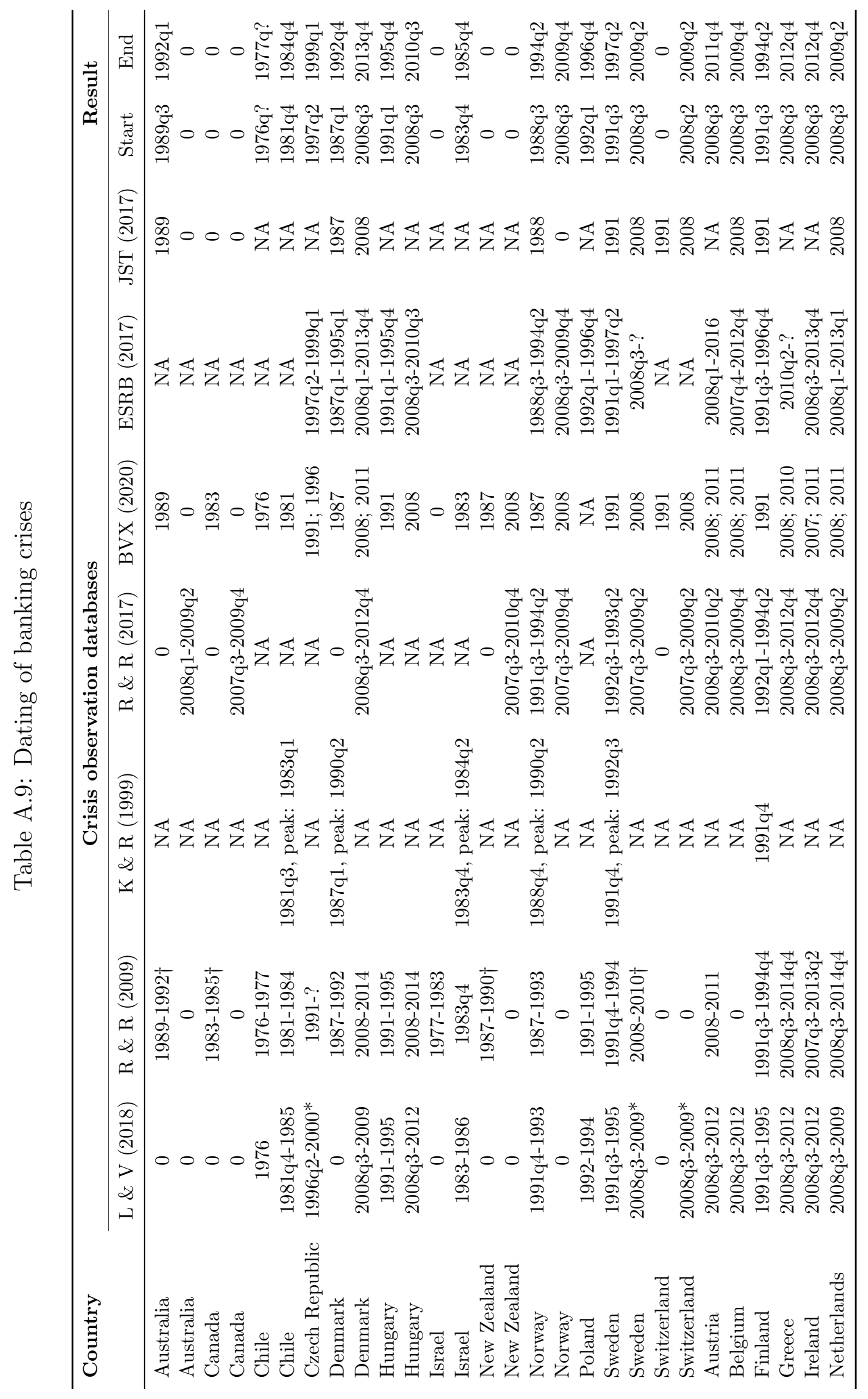




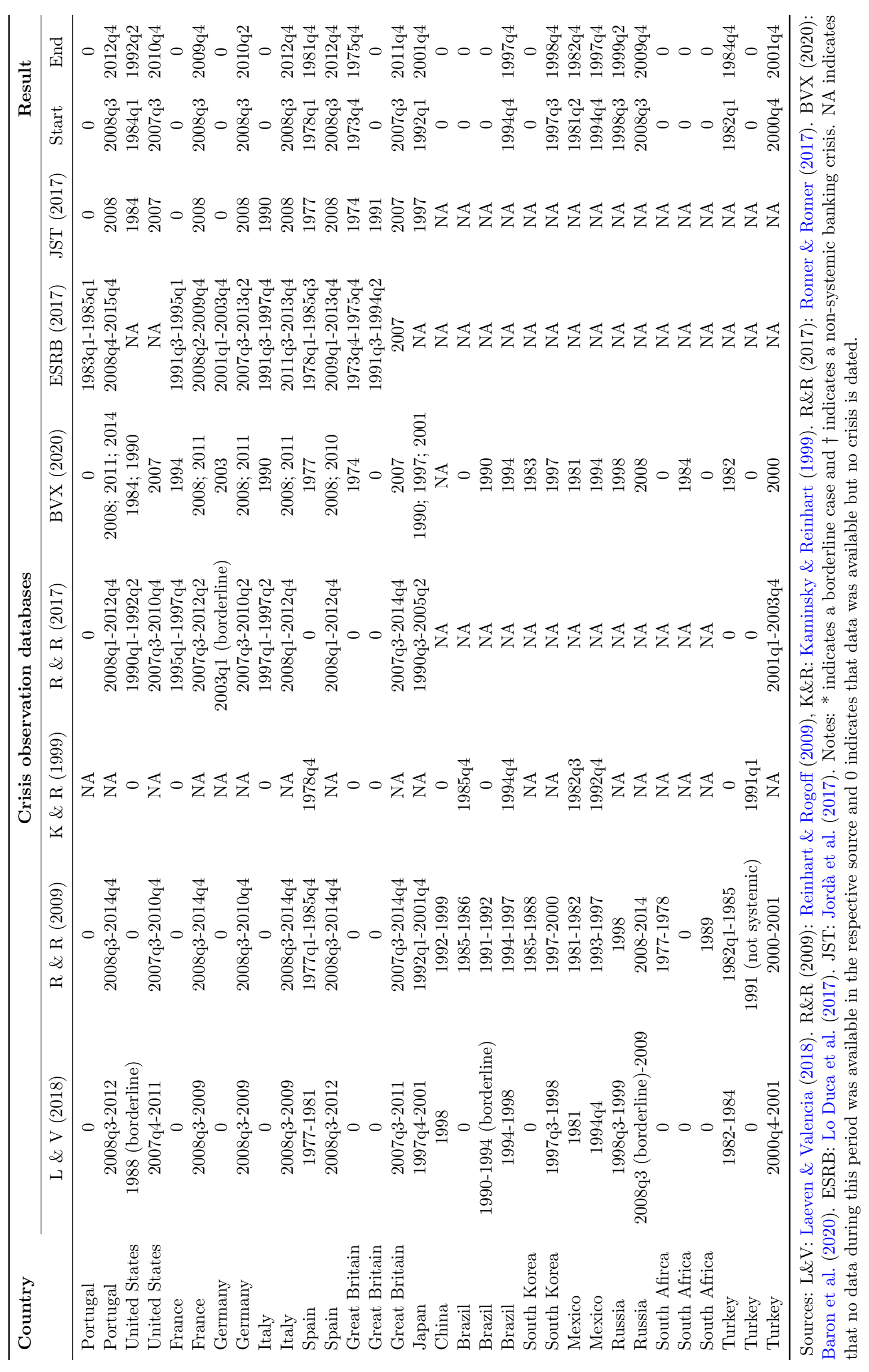


Table A.10: Interacting the exposure index with financial development

\begin{tabular}{lcc}
\hline Variable & \multicolumn{2}{c}{ Models } \\
\cline { 2 - 3 } & $(1)$ & $(2)$ \\
\hline Constant & $-3.393^{* * *}$ & $-3.086^{* * *}$ \\
& $(0.153)$ & $(0.184)$ \\
Crisis risk-weighted exposure index & $0.310^{* * *}$ & 0.022 \\
& $(0.026)$ & $(0.110)$ \\
Private debt-to-GDP ratio & $0.003^{* *}$ & 0.0003 \\
& $(0.001)$ & $(0.001)$ \\
Exposure index * private debt ratio & & $0.002^{* * *}$ \\
& & $(0.001)$ \\
\hline Observations & 4,512 & 4,512 \\
Log Likelihood & $-1,014.249$ & $-1,010.242$ \\
Akaike Inf. Crit. & $2,034.498$ & $2,028.484$ \\
\hline
\end{tabular}

Notes: $* * *, * * *$ indicate significance at the $10 \%, 5 \%$, and $1 \%$ confidence level, respectively. Depicted are the estimations of two augmented exposure-based model specifications over the pooled sample including the private debt-to-GDP ratio as a proxy for financial development (King \& Levine, 1993; Ang, 2008). The interaction term between the exposure index and the private debt-to-GDP ratio assumes the entire significance of both conventional coefficients when included: The exposure index's predictive power of banking crises is positively dependent on financial development. Its independent contribution is insignificant. 


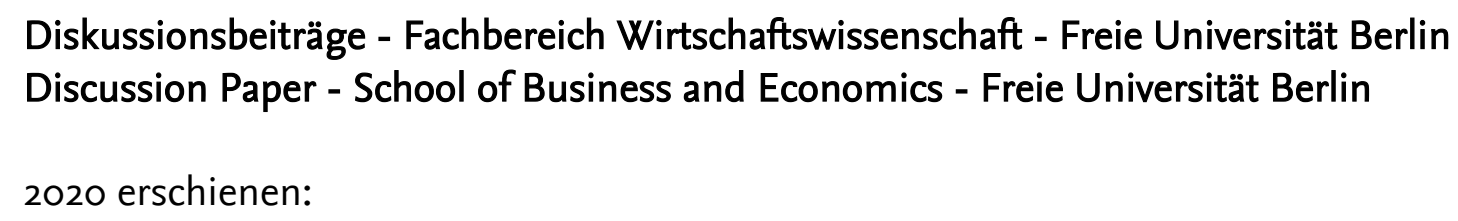

2020/5 BÖNKE, Timm; Rick GLAUBITZ; Konstantin GÖBLER; Astrid HARNACK; Astrid PAPE und Miriam WETTER: Die Entwicklung und Prognose von Lebenserwerbseinkommen in Deutschland Economics

2020/6 HUNDSDOERFER, Jochen und Eva MATTHAEI: Gender Discriminatory Taxes, Fairness Perception, and Labor Supply FACTS

2020/7 ZHU, Junbing und Theocharis GRIGORIADIS: Chinese Dialects, Revolutionary War \& Economic Performance

Economics

2020/8 POLUGODINA, Maria und Theocharis GRIGORIADIS: East Prussia 2.0: Persistent Regions, Rising Nations

Economics

2020/9 DOMBI, Akos; Theocharis GRIGORIADIS und Junbing ZHU: Antiquity and capitalism: the finance-growth perspective Economics

2020/10 AHMED LAHSEN, Amina; Alan T. PIPER und Ida-Anna THIELE: Kim Jiyoung, Born 1982, and the Labour Market: Overeducation, Gender, Income and Life Satisfaction. Panel evidence from Korea Economics 
2020/11 COLEMAN, Winnie und Dieter NAUTZ: The Credibility of the ECB's Inflation Target in times of Corona: New Evidence from an Online Survey Economics

2020/12 SYDOW, Jörg; Georg SCHREYÖGG und Jochen KOCH: Current interest in the theory of path dependence: a short update on the occasion of the 2019 AMR Decade Award

Management 